\title{
nate \\ Overcoming the Blood-Brain Barrier. Challenges and Tricks for CNS Drug Delivery
}

\author{
Luca Anna Bors and Franciska Erdő * \\ Pázmány Péter Catholic University, Faculty of Information Technology and Bionics, Práter u. 50a, \\ H-1083 Budapest, Hungary; bors.luca.anna@hallgato.ppke.hu \\ * Correspondence: erdo.franciska@itk.ppke.hu
}

Received: 26 January 2019; Accepted: 26 February 2019; Published: 28 February 2019

\begin{abstract}
Treatment of certain central nervous system disorders, including different types of cerebral malignancies, is limited by traditional oral or systemic administrations of therapeutic drugs due to possible serious side effects and/or lack of the brain penetration and, therefore, the efficacy of the drugs is diminished. During the last decade, several new technologies were developed to overcome barrier properties of cerebral capillaries. This review gives a short overview of the structural elements and anatomical features of the blood-brain barrier. The various in vitro (static and dynamic), in vivo (microdialysis), and in situ (brain perfusion) blood-brain barrier models are also presented. The drug formulations and administration options to deliver molecules effectively to the central nervous system (CNS) are presented. Nanocarriers, nanoparticles (lipid, polymeric, magnetic, gold, and carbon based nanoparticles, dendrimers, etc.), viral and peptid vectors and shuttles, sonoporation and microbubbles are briefly shown. The modulation of receptors and efflux transporters in the cell membrane can also be an effective approach to enhance brain exposure to therapeutic compounds. Intranasal administration is a noninvasive delivery route to bypass the blood-brain barrier, while direct brain administration is an invasive mode to target the brain region with therapeutic drug concentrations locally. Nowadays, both technological and mechanistic tools are available to assist in overcoming the blood-brain barrier. With these techniques more effective and even safer drugs can be developed for the treatment of devastating brain disorders.
\end{abstract}

Keywords: structure of the blood-brain barrier; models of the blood-brain barrier; drug delivery across the blood-brain barrier; nanocarriers; nanoparticles; vectors; intranasal delivery; efflux transporter inhibition; ultrasound-microbubbles

\section{Introduction}

The capillary microvessels of the brain have evolved to constrain the movement of molecules and cells between blood and brain, providing a natural defense against circulating toxic or infectious agents. The relative impermeability of the blood-brain barrier (BBB) results from tight junctions and adherens junctions between capillary endothelial cells formed by cell adhesion molecules. Brain endothelial cells also possess few alternate transport pathways (e.g., fenestra, transendothelial channels, pinocytotic vesicles), and express high levels of active efflux transport proteins, including P-glycoprotein (P-gp, MDR-1 or ABCB1) and breast cancer resistance protein (BCRP, ABCG2). The BBB maintains essential brain homeostasis but as a result, represents a significant impediment to the effective treatment of many brain diseases [1,2].

Current strategies to enhance drug delivery to the brain are either focused on locally circumventing the BBB through direct injections or nasal drug applications, for example, or globally through the bloodstream (using targeted delivery approaches or by opening the blood-brain barrier). Many approaches to enhance drug delivery across the BBB are under development, both by academic 
research groups as well as pharmaceutical and biotechnology companies. To translate basic (academic) research into safe and effective treatments for patients with devastating brain diseases, many steps in many different research areas are required. The pharmaceutical formulation (chemistry, manufacturing, control, analytics, and selection of proper nanocarriers), pharmacology and pharmacokinetics (drug delivery, neuroscience, and crossing the blood-brain barrier), and safety (toxicology, behavioral, route of drug administration, and chronic treatment) concerns should be harmonized and taken into account. One of the major challenges in the area of brain delivery is first to find an efficient vector for brain delivery using a physiological pathway mechanism to cross the BBB. These vectors can be in the form of peptides, proteins, antibodies, or some other specific formulation, such as nanoparticles, which target a specific receptor at the BBB and will cross the BBB by transcytosis.

In this review, the authors give an overview of the different advanced technologies and tricks on how to cross the BBB, and how to deliver pharmacologically active molecules to the central nervous system (CNS) target site. This article attempts to provide a synthesis of the existing knowledge of the observations and findings from the last decades on the structure and function of the BBB and classical technological approaches to overcome this physiological barrier. It also includes the newest developments and methods for modeling and crossing the blood-brain interfaces (e.g., dynamic chip models of the BBB, nanocarriers, vectors, and efflux transporter modulation to help the brain uptake of therapeutic drugs).

\section{Anatomy, Physiology and Molecular Constituents of Blood-Brain Barrier}

The mature blood-brain barrier (BBB) is composed of capillary endothelial cells (ECs) tightly connected with tight junctions (TJs) and adherens juntions (AJs) that prevent paracellular transport [3] and have a low pinocytotic activity [4,5], although limited transcellular transport does occur [6]. In addition, the BBB is influenced by closely associated perivascular astrocytic end-feet, pericytes, and microglia [7] (Figure 1). These different cell types play essential roles in BBB induction and maintenance by regulating the proliferation, migration, and vascular branching of the brain endothelial cells. Additionally, the basement membrane provides structural support around the pericytes and endothelial cells. The basal lamina is contiguous with the plasma membranes of the astrocyte end-feet [8]. The BBB provides strong resistance to movement of ions, with transendothelial electrical resistance (TEER) around $1500 \mathrm{X} \mathrm{cm}^{2}$ [5], 100 times higher than that for peripheral microvessels [9,10].

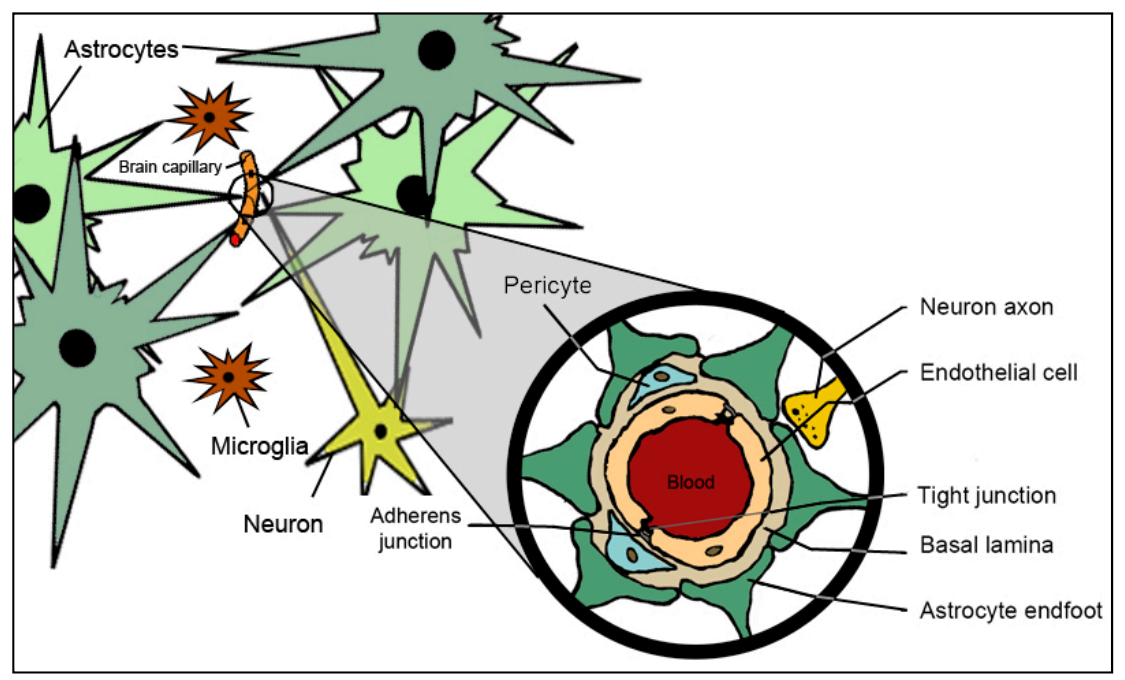

Figure 1. Shematic structure of the blood-brain barrier (BBB). The brain capillary endothelial cells (ECs) connected to each other by tight junctions (TJs) and adherens junctions (AJs). The endothelial cells are surrounded by basal membrane which also covers the connecting pericytes. Around the brain microvessels astrocyte endfeet are also essential providers of the barrier function. Additional supporting cell types are microglia cells and the connecting neurons. 


\subsection{Endothelial Cells}

Compared to peripheral vasculature, BBB ECs are characterized by increased mitochondrial content, exhibit minimal pinocytotic activity, and lack fenestrations [11-14]. The restricted paracellular permeability of the capillary EC layer is warranted by two intercellular molecular binding systems: the AJs and the TJs. TJs are dynamic complexes of multiple protein constituents including junctional adhesion molecules (JAMs), occludin, claudins (i.e., claudin-1, -3, and -5), and membrane-associated guanylate kinase (MAGUK)-like proteins (i.e., ZO-1, -2 and -3) [8]. AJs are composed of multiple protein components including vascular endothelium (VE) cadherin, actin, nectin, and catenin [15]. Both on the basolateral and on apical surfaces of ECs there are different types of transporter proteins expressed.

The schematic overview of the most important transporter systems located in the BBB ECs is presented in Figure 2.

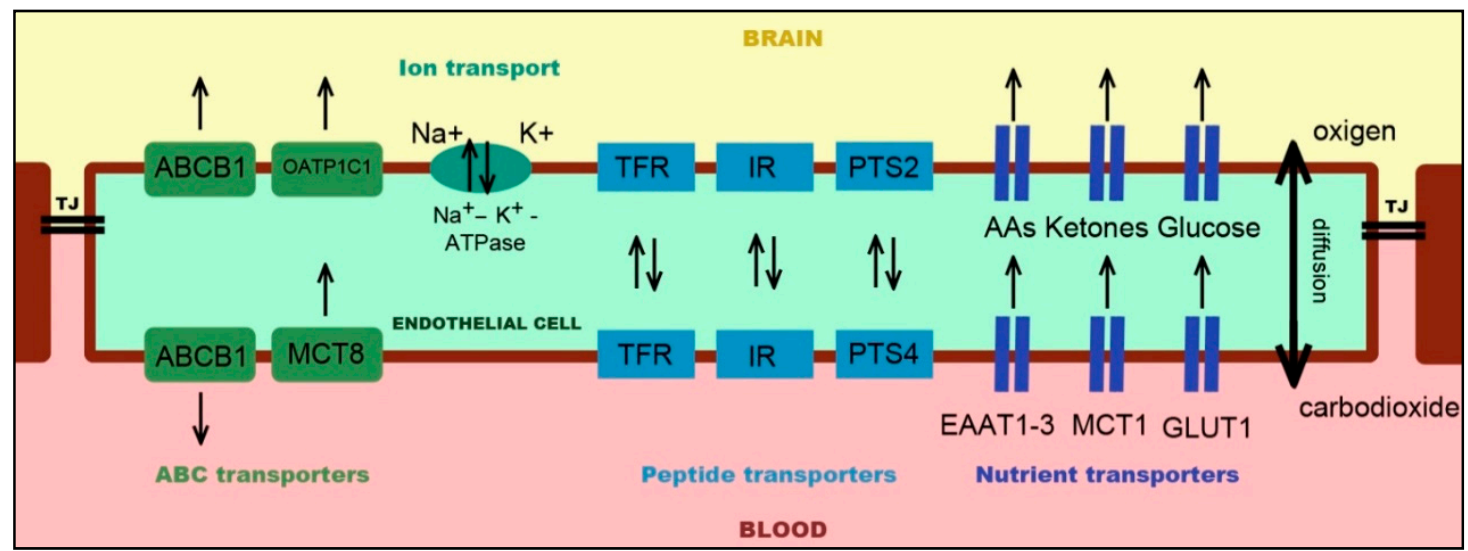

Figure 2. The schematic representation of the most important transport systems at the blood-brain barrier endothelial cells.

\subsection{Astrocytes}

Astrocytes are glial cells that help, support and protect neurons by controlling neurotransmitter and ion concentrations to maintain the homeostatic balance of the neural microenvironment, by modulating synaptic transmission and by regulating immune reactions [16] and by interacting with endothelial cells through their endfeet projections that encircle the basolateral side of cerebral capillaries [17].

\subsection{Pericytes}

Pericytes regulate (1) BBB integrity, i.e., tight or adherens junctions and transcytosis across the BBB; (2) angiogenesis, i.e., microvascular remodeling, stability, and architecture; (3) phagocytosis, i.e., clearance of toxic metabolites from the central nervous system; (4) cerebral blood flow, capillary diameter; (5) neuroinflammation, i.e., leukocyte trafficking into the brain; and (6) and multipotent stem cell activity [18].

\subsection{Microglia}

Microglia, the primary immune cells of the brain, are ubiquitously distributed in the CNS and are activated in response to systemic inflammation, trauma, and several CNS pathophysiologies [12,19-21]. Microglial activation in response to pathophysiological stressors can trigger changes in cell morphology, which include reduced complexity of cellular processes and transition from a ramified morphology to an amoeboid appearance [19].

Activation of microglia is associated with altered $\mathrm{TJ}$ protein expression and increased BBB permeability [22]. Microglia are a supportive cell type for the proper function of the BBB. 


\section{In Vitro, In Situ, and In Vivo Models for Testing the Blood-Brain Barrier}

\subsection{In Vitro Modeling}

\subsubsection{Static In Vitro BBB Models}

The simplest in vitro BBB model consists of a monoculture of cerebral endothelial cells seeded on a semi-permeable support under static culture conditions.

Brain endothelial cells. The brain endothelial cells used in in vitro BBB modeling can be primary cells or immortalized cell lines. The most frequently used primary brain endothelial cells are isolated from rat, mouse, bovine, porcine, and human [23] Primary cells might not be a convenient choice for every in vitro study/testing due to limited availability, high costs, time-consuming preparations (including the necessity for special skills required for the cellular isolation), and cultures being susceptible to internal and external contamination $[23,24]$. On the other hand, immortalized cell lines remain viable over many passages with a higher experimental reproducibility between tests compared with primary cells [25]. Thus, making these cells relatively reliable, easily accessible, and affordable considering that culture preparation time and costs are reduced [26]. The most frequently used cell lines for modeling the BBB are summarized in Table 1.

Table 1. Immortalized cell line models of BBB (modified from Abbot et al., 2014 [23]).

\begin{tabular}{ccc}
\hline Cell Line & Species, Transfection & Recent References \\
\hline RBE4 & Rat (2) & Branca et al., 2018 [27] \\
\hline hCMEC/D3 & Human (5) & Kuroda et al., 2018 [28] \\
\hline MBEC4 & Mouse (1) & Mizutani et al., 2016 [29] \\
\hline *bEND3 & Mouse (3) & Zhou et al., 2018 [30] \\
\hline TR-iBRB2 & Rat retina (4) & Kinoshita et al., 2018 [31] \\
\hline GP8.3 & Rat (1) & Motta et al., 2015 [32] \\
\hline GPNT & Rat (1) & Tega et al., 2018 [34] \\
\hline TR-BBB13 & Rat (4) & Ishisaka et al., 2014 [35] \\
\hline RBEC1 & Rat (1) & Blecharz-Lang et al., 2018 [36] \\
\hline cEND & Mouse (3) & Zuccolo et al., 2017 [37] \\
\hline *bEND5 & Mouse (3) & Dasgupta et al., 2011 [38]
\end{tabular}

Transfection vector/method (1) SV40 large T antigen; (2) Adenovirus E1A gene; (3) Polyoma virus middle T antigen; (4) Transgenis ( $\mathrm{Tg}$ ) rat or mouse harboring temperature sensitive SV40 large T antigen; (5) Sequential lentiviral transduction of hTERT and SV40 large T antigen. * Available from ECACC (European Collection of Animal Cell Cultures) and ATCC (American Type Culture Collection)

From in vitro co-culture models, generally, co-cultures of cerebral endothelial cells with astrocytes and pericytes (bi- or triple co-cultures) are widely used since they play a crucial role in the development of the paracellular tight junctions of the BBB and modulating endothelial cell functions [24,26].

Asrtocytes. Although they are not in direct contact with endothelial cells in the neurovascular unit due to the presence of the basal membrane astrocytes, the interaction between these two cells is the best characterized (for review see refs Abbot et al., 2006 and Alvarez et al., 2013 [17,39]). The effect of astrocytes during adulthood on the inter-endothelial junctions is especially important as it largely determines permeability and also on the modulation of transporter expression. Astrocytes play a crucial role in the development of the complexity of tight junctions [40] and upregulation of the efflux transporters ABCB1 [41] and ABCG2 [24,42].

Pericytes. Although pericytes are the closest neighbors of endothelial cells in vivo, their effect is far less well characterized than that of the astrocytes. They have multiple roles, such as contractile, 
immune, phagocytic, and angiogenic functions. Pericytes also contribute to the formation of the basement membrane by synthesizing laminin, type IV collagen, and glycosaminoglycans. Besides being important elements of the BBB, they are a source of adult pluripotent stem cells as well [24,43].

Stem cells. Stem cells are a promising source of cells for the generation of in vitro human BBB models because these cells have the capacity to differentiate into cerebral endothelial cells, they can give rise to a significant number of BBB cells.

Embryonic stem cells (ESCs) are an alternative pluripotent stem cell therapy option due to their ability to differentiate into various types of brain cells in addition to their indefinite self-renewal abilities in vitro [44]. Neural stem cells (NSCs) are multipotent stem cells in adult brains that, unlike ESCs, have a decreased potential of self-renewal and normally, for the purpose of repair, differentiate into only one cell lineage of the tissue [45]. NSCs can differentiate into neuronal cells and, hence, have huge potential for the generation of in vitro human BBB models featuring a more complex neurovascular unit (NVU) system encompassing both vascular and brain tissue [26,45]. Induced pluripotent stem cells (iPSCs) are potential stem cells that can be used as a replacement therapy for human cellular models. The two main advantages of iPSCs are the avoidance of the use of ESCs for ethical reasons and the ability to be generated from the patients themselves [46]. The use of mesenchymal stem cells (MSCs) offers huge potential for application in the treatment of brain diseases, not only because MSCs are easily isolated, but they can also be easily expanded from tissues without ethical concerns. Recent work has shown strong similarities between MSCs and pericytes [47]. Similar multipotential stem cell activity has been exhibited in CNS microvascular cells to that seen in MSCs and also pericytes and MSCs express many of the same cell surface markers [48].

To enable drug transportation studies, advances in the culture setup have been made, resulting in cell culture on a filter membrane suspended in a well, the so-called Transwell system [23]. The Transwell system is essentially a side by side vertical diffusion system which comprises a microporous semipermeable membrane (on which cells can be seeded submerged in feeding medium [49] that separates the vascular and parenchymal side compartments. Transwell systems are ideal for linear kinetic studies of transport due to the fixed volumes of each compartment, but there are substantial limitations inherent to these platforms that need to be taken into consideration. For example, the lack of a three-dimensional structure present in vivo and lack of endothelial exposure to physiological shear stress which limits the differentiation of the endothelium into a BBB phenotype (or maintenance of BBB properties in fully differentiated cells) [26]. The possible seeding arrangements can be seen in Figure 3. 
A

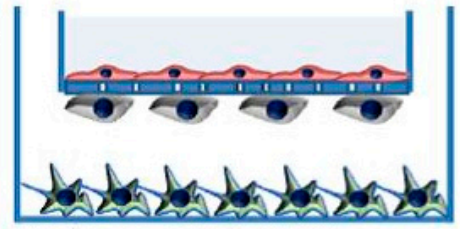

Nakagawa et al., 2008

TEER: $354 \Omega \times \mathrm{cm}^{2}$ (RAT)

B

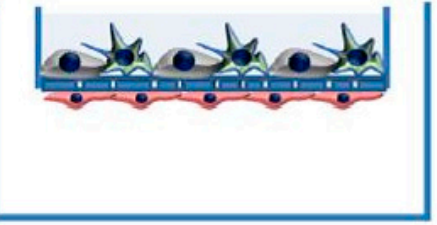

Toyoda et al., 2013

TEER: $329 \Omega \times \mathrm{cm}^{2}$ (RAT)

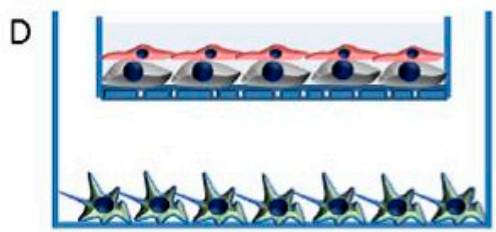

Vandenhaute et al., 2011

(BOVINE/RAT)
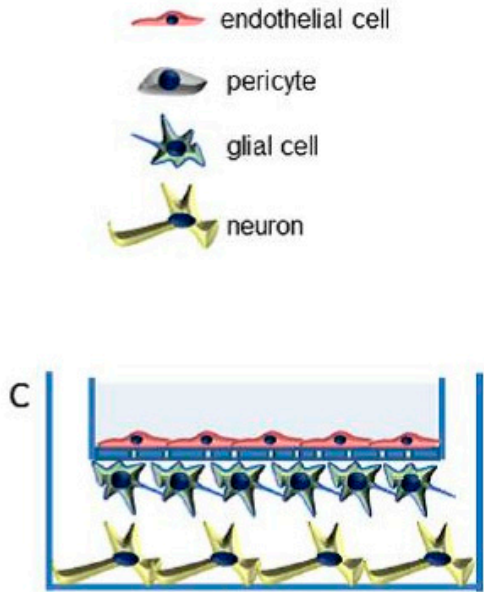

Xue et al., 2013

TEER: $268 \Omega \times \mathrm{cm}^{2}$ (RAT)

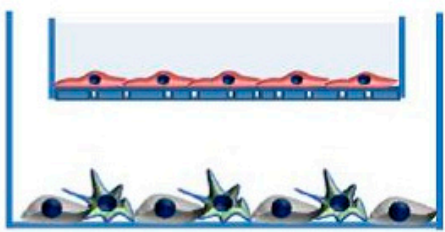

Vandenhaute et al., 2011

(BOVINE/RAT)
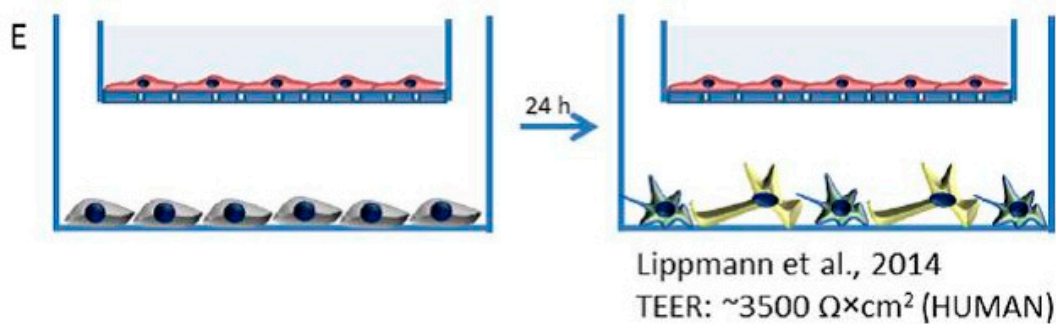

Figure 3. In vitro BBB models using three different cell types. Cerebral endothelial cells are cultured on semi-porous membranes in the presence of pericytes, astrocytes, and/or neurons in different arrangements. (From Wilhelm and Krizbai, 2014 [24] with permission). Panel A [50], B [51], C [52], D [53], E [54].

\subsubsection{Dynamic In Vitro BBB Models}

In dynamic systems, brain endothelial cells are cultured in the lumen of hollow fibers inside a sealed chamber and are exposed to flow, while the NVU is seeded in the extraluminal compartment. Intraluminal flow is generated by a variable-speed pulsatile pump that can be regulated to produce desirable intraluminal pressure physiologically comparable to that observed in capillaries in vivo. Low permeability to intraluminal polar molecules, high TEER, negligible extravasation of proteins, expression of specialized transporters, efflux systems, and ion channels are several significant advantages of dynamic in vitro BBB models.

Microfluidic-on-chips as a type of dynamic 3D model and novel class of micro-engineered laboratory models of BBB combine several advantages of current in vivo and in vitro models $[55,56]$ (see also Figure 4). 


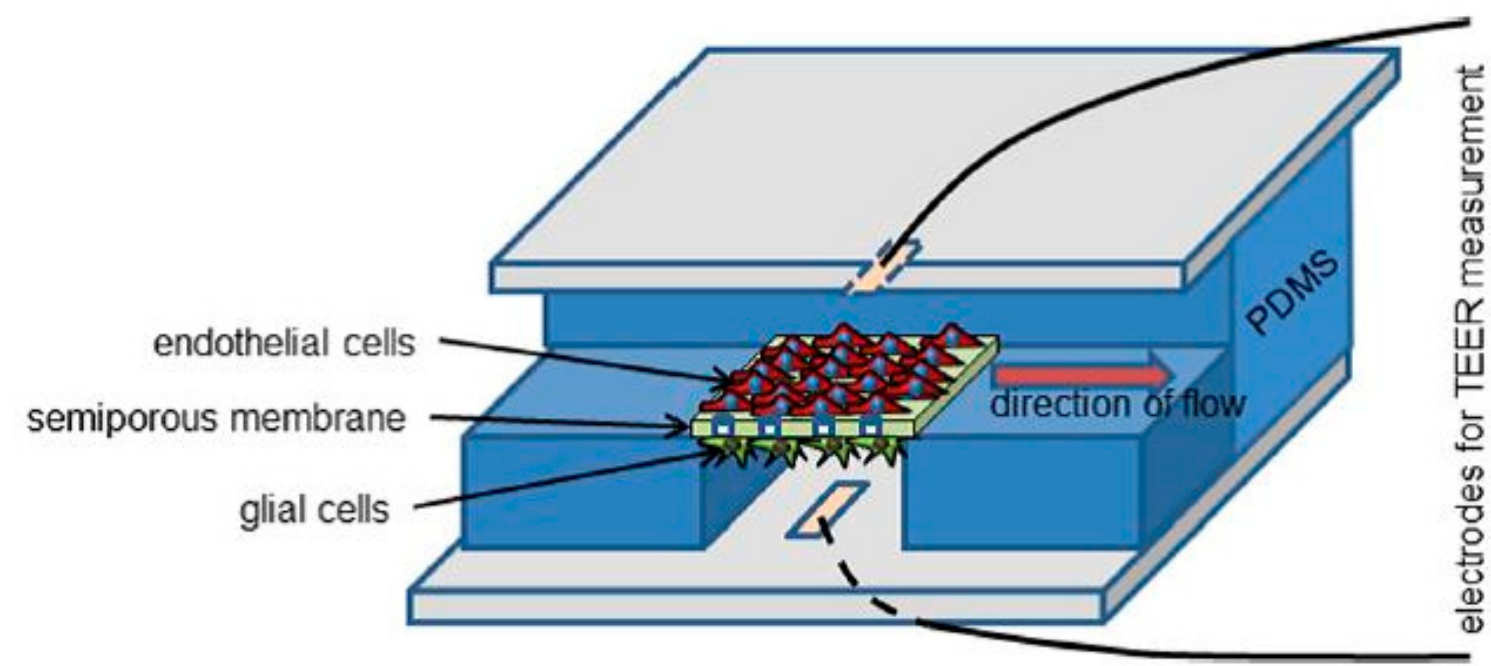

Figure 4. Schematic representation of a microfluidic model. Cerebral endothelial and glial cells are cultured on the two sides of a semi-porous membrane placed at the interface of two microchannels. (From Wilhelm and Krizbai, 2014 [24] with permission).

In a typical tissue-on-a chip embodiment, microfluidic channels are fabricated using soft lithography techniques by molding an elastomeric material, polydimethylsiloxane (PDMS), against a photo-defined master mold and a porous cell culture substrate is then sandwiched and sealed between the channel networks [57]. This system improves BBB modeling by having more realistic dimensions and geometries [58-60].

\subsection{In vivo Modeling}

Because of the complexity of the BBB and the realization that many BBB properties are not constant but vary with disease, development, and drug exposure, it has been difficult to develop a small toolbox of in vitro or in silico models that adequately predict drug transport and availability to the CNS. As a consequence, in vivo testing of brain drug uptake and equilibration is still considered the "gold standard" of any CNS drug delivery program.

In vivo CNS drug penetration experiments are designed along classic pharmacokinetic lines to measure two primary parameters: the rate at which a compound crosses into brain (i.e., BBB permeability-surface area product (PS)) and the extent to which the compound distributes within the CNS (i.e., brain distribution volume or partition coefficient (Kp, brain)) $[23,61,62]$.

It can be important to distinguish the concentration of drug that is free or unbound from the total drug concentration in brain and serum because the free drug concentration correlates best with pharmacodynamics models of activity. Many drugs bind significantly to proteins and lipids based upon lipophilicity and other factors. In such cases, total concentration can differ greatly from the free drug concentration that is usually the driving force for drug diffusion and equilibration.

The unbound fraction of drugs $\left(\mathrm{f}_{\mathrm{u}}\right)$ can be determined from total concentration by ex vivo equilibrium dialysis or ultrafiltration [61]. Once $f_{u}$ is measured, the free concentration $\left(C_{u}\right)$ can be calculated as

$$
\mathrm{C}_{\mathrm{u}}=\mathrm{f}_{\mathrm{u}} \times \mathrm{C}_{\text {tot }}
$$

$\mathrm{C}_{\mathrm{u}}$ can also be measured directly in the brain by in vivo cerebral microdialysis $[61,63]$. The possible drug-BBB transporter interactions can also be verified by microdialysis with the determination of $\mathrm{AUC}_{\mathrm{brain}} / \mathrm{AUC}_{\mathrm{blood}}$ ratio in the transporter substrate or substrate plus inhibitor-treated animals $[64,65]$.

The permeability of BBB is changed in certain types of brain pathologies, such as malignant gliomas, ischemic or hemorrhagic stroke or epilepsy. To mimic the malignant pathologic conditions many preclinical models have been developed. The early versions of genetically engineered mouse 
(GEM) models of brain tumors were based on the constitutional inactivation of tumor suppressor genes and/or the introduction of activated oncogenes into the germline. Later the contemporary GEM possessing produced inducible tumor suppressor gene knockouts, oncogene knockins, and improved cell type-specificity control over genetic alteration induction [66,67]. Although in recent years the neuro-oncology research community has directed more attention to the use of patient-derived xenograft models for therapeutic testing, the syngeneic, immunocompetent rodent models and the GEM models continue to serve a critically important role in brain tumor research, mainly for preclinical testing of therapies [66]. Many advanced techniques are used to assist and improve drug brain-tumor exposure, for review see Raucher et al. 2018 [68].

\subsection{In Situ Modeling}

In some situations, additional information is required over the in vivo collected data regarding the mechanisms involved that restrict drug uptake into the brain at the BBB. With the normal in vivo approach, limits are placed on the degree to which an investigator can control or change brain blood flow and free drug concentration or block transport or metabolic mechanisms. Knockout animals are available for several key BBB transporters, such as p-glycoprotein, breast cancer resistance protein, multidrug resistance protein-4, and organic acid-transporting polypeptide. However, with current transporter knockouts, the alteration is not just at the BBB but at all sites within the CNS that usually express the transporter. This can lead to complexity in evaluating the separate role of the BBB in overall brain distribution of the compound.

As alternatives to direct in vivo analysis, in situ perfusion and brain efflux index methods are available for more specific studies of BBB transport. These approaches complement the standardised IV administration method but allow greater flexibility in studying factors that may alter transport [69]. The in situ perfusion method utilizes the in vivo structure of the BBB and cerebral tissues and simply superimposes its own vascular perfusion fluid in replacement of the animal's circulating blood (Figure 5). The particular key advantage of this method is the facile control of perfusate solute concentration which can be altered over a much greater range than generally tolerated in vivo.

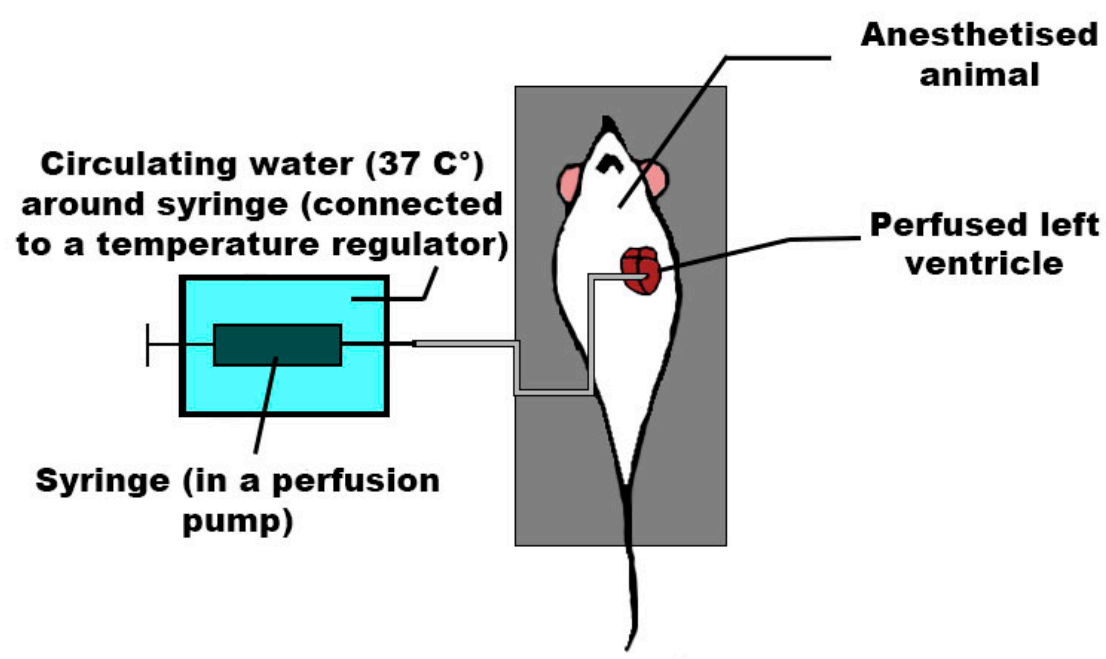

Figure 5. Typical setup for in situ brain perfusion with syringe, infusion pump, temperature control, and circulating water bath.

\section{Focus on Drugs-Strategies to Improve Drug Delivery to the Brain}

\subsection{Nanocarriers, Nanoparticles, and Vectors}

Some types of nanocarriers are presented in Figure 6. Size is a crucial parameter of the nanoparticles (NPs) - the delivery to the targeted tissue, the cellular uptake and the ability to reach 
target proteins - as even chemical reactions are size dependent. The optimal size of a NP also depends on the specific location and type of targeted tissue [70], for example, most tumors have a vascular pore cutoff size between 380 and $780 \mathrm{~nm}$ [71]. However, Kang et al. have shown that for a gold NP has to be around 10 to $20 \mathrm{~nm}$ in diameter to effectively cross the BBB, while particles around 50 and $100 \mathrm{~nm}$ diameter were not distributed well enough into the brain [72,73].

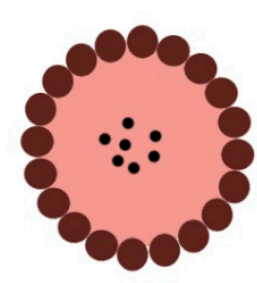

Lipid NP

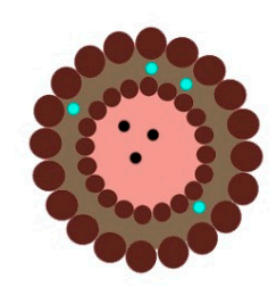

Liposome

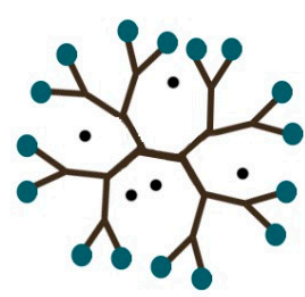

Dendrimer

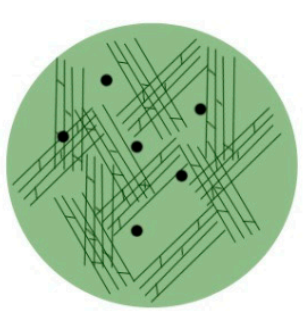

Polymeric NP

Figure 6. Schematic representation of nanocarriers: a lipid nanoparticle, a liposome with lipophilic (cyan dot) and hydrophilic (black dot) drug, the dendrimer and a polymeric nanoparticle.

Size is also important to predict the elimination of the NP: Polymeric NPs larger than $200 \mathrm{~nm}$ are mostly sorted out by the spleen, NPs between 100 and $150 \mathrm{~nm}$ are captured by the Kupffer cells in the liver, and under $5.5 \mathrm{~nm}$ compounds leak out from the kidney [74]. Intravenously injected nanoparticles around $10 \mathrm{~nm}$ diameters have reached liver, spleen, kidney, testis, thymus, heart, lung and brain, while larger particles (50 nm, $100 \mathrm{~nm}$, and $250 \mathrm{~nm}$ ) were only primarily found in blood, liver, and spleen [75].

The shape of a carrier can influence its cellular uptake. For example, Kajino et al. tested the diffusion of spherical, cubic, rod-like, or worm-like shapes in the body with gold nanoparticles and Madden et al. with particle replication in non-wetting templates (PRINT) micro- and nanoparticles [76,77].

Cyclodextrins (CDs) are cyclic oligosaccharides made from starch [78]. There are three different variations of cyclodextrin: alpha- (consisting 6 glucopyranose), beta- (7GP) and gamma-cyclodextrin (8GP). The outer ring of CD is highly hydrophilic while the inside is more hydrophobic. Thus, CDs are perfect for delivering hydrophobic compounds into a hydrophilic environment, such as the blood. The different sizes and numbers of entrapping CDs can be optimized for trapping a wide variety of hydrophobic molecules [79].

In addition to their nanocarrier function, CDs also can be used as an active compound; CDs interact with lipid membrane rich in cholesterol and sphingolipids. It means CDs have cytotoxic and hemolytic properties due to their membrane alteration, such as increased fluidity and permeability [80].

To study the relationship between the blood-brain barrier and CDs Monnaert and coworkers used native, methylated, and hydroxypropylated CDs on a tight culture model [81]. Native CDs have significantly increased sucrose permeability. The lipid destructive effects were attenuated by methylation in the case of alpha-CD, while hydroxypropiltion worked for only beta- and gamma-CDs. In addition, 12-alkyldimethylammonium-beta-CD (DMA-D(12)-CD) was shown to be non-toxic on cultured bovine brain endothelial cells at less than $10 \mathrm{nM}$ concentration while having $30 \%$ of passage through BBB model [82]. Two methylated CDs RAMEB (randomly methylated-beta-CD) and CRYSMEB (partially methylated crystallized-beta CD) increased the transport of doxorubicin in bovine brain endothelia cells by extracting cholesterol from the cell membrane and, thus, altering the activity of a BBB efflux transporter, P-glycoprotein [83].

Lipid nanoparticles (NPS). Lipid NPs can be divided into two big groups: liposomes (LPs) and other lipid NPs, such as solid lipid NPs (SLN), and nanostructured lipid carriers (NLC) [84].

LPs are rather safe and selective therapeutic tools, composed of one or more lipid bilayers, and have been studied and used since the 1970s. They also can encapsulate lipophilic as well as lipophobic compounds in a wide variety of sizes $[85,86]$. However, non-targeted liposomes will 
not effectively pass a healthy BBB, but with surface modification, for example, adding polymers, polysaccharides, peptides or antibodies, the characteristics and targets of LPs can be specified. Furthermore PEGylation is used to prevent liposomes from being eliminated by the immune system and improve biodistribution [87]. As for transporter-mediated crossing of the BBB, transferrin was added to the surface of LPs, to deliver gene therapy in Parkinson's disease animal models [88].

Cationic LPs are ideal for delivering drugs and genetic material due to their positively charged surface, which facilitates interaction with the cell membrane and enhances uptake. Their advantage is also their disandvantage: due to the cationic properties, peripheral tissues and serum proteins bind and block them from being able to pass the BBB [87]. Song and coworkers have constructed an ApoE-containing high density lipoprotein (HDL) inspired nanocarrier [89], which is BBB permeable [90] and has high A $\beta$-binding affinity [91], for the treatment of Alzheimer's disease (AD).

SLNs are made of lipids which stays solid at body temperature. Their lack of the hydrophilic domain makes it possible to carry lipophilic compounds [84] but allows nanoparticle to cross the BBB with ease [92]. NLCs are modified SLNs that have improved drug loading capability and are more biocompatible.

A novel approach is on the horizon: nanovesicles derived from cells, so called exosomes, are potential new lipid nanocarriers of genes, proteins, and drugs $[39,93,94]$. Exosomes are a sub-population of specialized membranous extracellular vesicles derived from endocytotic compartments, are 30 to $100 \mathrm{~nm}$ in size, and are actively secreted by almost all cell types [95]. The exosomes ability to cross the BBB has been studied in zebrafish and mouse models [96,97]. Only exosomes isolated from brain endothelial cells could cross the BBB and deliver cargo into the CNS suggesting potential homo-tropism for the tissue of origin [97].

Polymeric nanoparticles (PNPs). PNPs consist of matrix-like solid colloids, and can be found in a wide variety of sizes from 1 to $1000 \mathrm{~nm}$. The polymers can have different natures: natural, such as albumin and chitosan or synthetic but every PNP is biocompatible and biodegradable [84].

Chitosan is a natural polysaccharide, derived from arthropods by the deacetylation of chitin and available in a wide variety of sizes/molecular weights and degree of acetylation and with surface PEGylation it also can cross the BBB and also can prolong its lifetime in the body [84]. Chitosan has minimal toxic properties and biocompatiblity [98], but chronic administration is not advised [84].

Poly-butyl cyanoacrylate (PBCA), poly-lactic acid (PLA), and poly-lactic-co-glycolic acid (PLGA) are the most popular synthetics but are fully biocompatible and biodegradable polymers, especially PLGA, which has a more controllable drug release kinetics and better encapsulation properties [84]. PBCA can be produced easily but has weaker drug delivery capabilities. It has rapid biodegradation and insufficient absorption compared to more hydrophilic and lipophilic molecules [84]. PBCAs are usually targeted to low density lipoprotein (LDL) receptors to make them pass the BBB in mouse and rat models and deliver neural growth factor (NGF) [99] or Tacrine (also delivered by Chitosan carriers) [100] into the CNS as a drug for Alzheimer's and Parkinson's disease therapy.

Dendrimers (DDs) are macromolecules composed of three layers of polymers: 1) a central core; 2) branches, which are attached to the core and determine the generation of the DD (i.e., equals the number of layers the branches consist of. For example, a DD with three layers of branches is indicated as a G3 DD), and 3) the terminal functional groups, which create the surface of the nanoparticle [87]. The surface can be specialized for its function. For example, with transferrin conjugation, which enables the DD to cross the BBB [101], or with PEGylation or carbohydrate groups where toxic side effects and immune response can be excluded $[102,103]$. The most used DD is poly-amidoamine (PAMAM), which is water soluble and can encapsulate hydrophobe compounds. For example, cationic PAMAM DDs of different generations are used with PEGylation, as a safe in vivo drug delivery system in stroke patients [104].

There are some examples of successful use of DDs in CNS therapies: There was a study performed for a potential therapy to slow down and prevent Alzheimer's disease with cationic phosphorous DDs that disrupted amyloid $\beta(\mathrm{A} \beta)$ and MAP-Tau aggregations [105]. G0-PAMAM DD was used 
with tetra-malermidopropionyl conjugated and helical $\beta$ peptide foldamers decorated on its surface and has been shown to successfully protect against $A \beta$ induced long term potential, memory loss in Alzheimer's disease [106]. G3 and G4 polypropylenimines with maltose coating, prevent $A \beta$ fibrillation in mice [102].

Magnetic NPs (MNP) are nanoparticles with a metal core (mostly iron-oxide) that has an unpaired electron, therefore, has magnetic property. Iron is the most popular core material due to its low toxicity and easy elimination through the endogenous iron metabolic pathway and is usually used in oxide form because it is a more stable state [87]. Multiple coating is used to enhance drug delivery, such as polysaccharides (dextrin), polyethylene-glycol (PEG), phospholipids, peptides, for protection of the metal core from the body, improve pharmacokinetics, lower toxicity [107]. Fluorophores/radionuclides are used for basic research and for diagnostic purposes [108]. Iron-oxide MNPs can also be used as a contrast agents for magnetic resonance image (MRI), and therapy via magnetic fluid hyperthermia (MFH) [109].

Gold NPs (AuNP) are also a popular form of metallic core NPs. AuNPs are mostly coated covalently with an organic layer to improve biocompability, biophysical properties, and targeting. They are available in a wide variety of optical and electric features and structures, such as nanospheres and nanorods [110]. AuNPs have low toxicity and also easily cross the BBB [111]. For example, a wheat germ agglutinin horseradish peroxidase (WGA-HRP) conjugated AuNPs has been shown to be able to cross the BBB through intramuscular injection in the diaphragm of rats [112]. They are also used for imaging as X-ray contrast agents for computer tomography (CT) [113].

Carbon nanotubes (CNT) are made of graphene cylinders with open ends. The number of graphene layers can determine the flexibility of the carrier: fewer layers mean more flexibility [114]. CNTs are used as a chemotherapy drug, RNA, and protein delivery agent and also as biosensors [115]. As a CNS treatment possibility, a multi-walled carbon nanotube was functionalized with an amine group (MWCNTs- $\mathrm{NH}_{3}{ }^{+}$) to effectively pass through the BBB via transcytosis in both in vitro and in vivo mouse models [116].

Some properties of nanocarriers and nanoparticles which are crucial for their penetration across the BBB are summarized in Table 2.

Table 2. Characterization of different nanocarriers/nanoparticles by size, charge and cerebral accumulation.

\begin{tabular}{|c|c|c|c|c|}
\hline Name & Diameter (nm) & Accumulation & Charge & References \\
\hline $\operatorname{CD}(\alpha / \beta / \gamma)$ & $14.6 / 15.4 / 17.5$ & $\begin{array}{c}\text { hydroxypropyl } \beta \text {-CD: AUC } \\
1.22, \operatorname{cmax} 1.03\end{array}$ & slightly positive & {$[117,118]$} \\
\hline LP & $\begin{array}{l}<100 ;>200 \text { decreased } \\
\text { penetration into the brain }\end{array}$ & $\begin{array}{l}\text { accumulate in ischemic } \\
\text { brain }\end{array}$ & $\begin{array}{l}\text { depends on lipid bilayer } \\
\text { compounds }\end{array}$ & {$[119,120]$} \\
\hline Cationic LP & $65,5-352$ & & positive & [121] \\
\hline SLN & $10-1000$ & $\begin{array}{l}38.4-42.7 \% \text { in brain with } \mathrm{Tf} \\
\text { conjugation }\end{array}$ & $\begin{array}{l}\text { Positive (stearylamine and } \\
\text { glycol chitosan) }\end{array}$ & {$[120,122,123]$} \\
\hline $\begin{array}{c}\text { Albumin } \\
\text { (nanoparticle) }\end{array}$ & $50-80$ & $\begin{array}{c}\text { L-BSA and BSA NPs } \\
\text { accumulate in intracranial } \\
\text { tumor }\end{array}$ & negative & [128-130] \\
\hline Chitosan & $10-80$ & $\begin{array}{l}\text { significant brain } \\
\text { accumulation with } \\
\text { RVG-Chito NP }\end{array}$ & positive & {$[131,132]$} \\
\hline Dendrimers (DD) & $1-100$ & & depends on surface groups & [120] \\
\hline DD PAMAM & $14-15$ & $\begin{array}{c}\text { G6 PAMAM has high } \\
\text { accumulation in brain of } \\
\text { HCA dogs }\end{array}$ & positive & {$[136,137]$} \\
\hline DD G13 & 24 & & depends on surface groups & [136] \\
\hline $\mathrm{MNP}\left(\mathrm{Fe}_{3} \mathrm{O}_{4}\right)$ & $10-300$ & up to $6 \mathrm{~h}$ no accumulation & & [138] \\
\hline AuNP & $5-200$ & (with PEG) low & & [139] \\
\hline CNT & 1 (diameter), >1000 (length) & $\begin{array}{l}\text { MWNTs- } \mathrm{NH}_{3}{ }^{+} \text {penetrates } \\
\text { the brain and accumulates }\end{array}$ & depending on crystalline order & {$[116,140]$} \\
\hline
\end{tabular}


Viral vectors are widely used for gene modification and delivery (Figure 7). This method can provide long-term expression of the transgene in non-dividing cells, especially with adeno-associated viral (AAV) vectors [141]. To get a sufficient quantity of therapeutic genes into the CNS, these vectors have to be engineered to be able to cross the BBB [142]. A major focus of recent gene therapy research has been in developing brain-tropic AAV vectors and understanding the mechanisms of their passage across the BBB. [143] AAV9 vectors are well tolerated IV viral vectors that can cross the endothelial cells of the BBB [144,145] via active-transport, while not compromising barrier integrity [146] and have promising results in clinical trials for their safety and their efficiency to transduce target cells, for example, in spinal muscular atrophy therapy [147-149], spinal muscle atrophy [150], and mucopolysaccharidosis IIIB (Sanfilippo syndrome) [151,152]. Zhang and coworkers showed that another four serotypes of recombinant AVV can also overcome the BBB: rAAVrh.10, rAAVrh.39, rAAVrh.43, and rAAV7 [153]. Simian virus 40 (SV40) is another safe to use viral vector for delivering genes into the CNS, mostly transducing cortical cells [154,155].

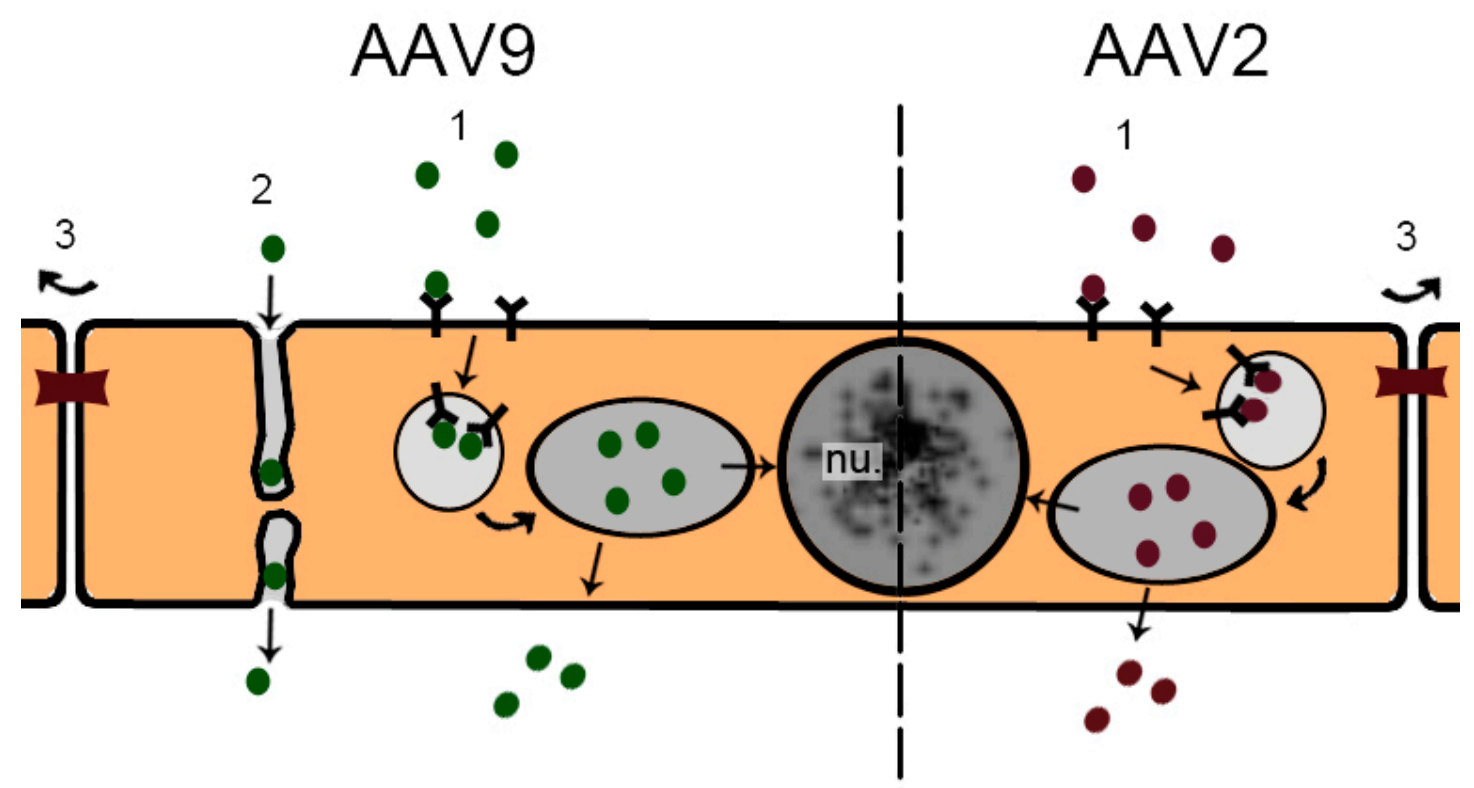

Figure 7. Adeno-associated viral 9 (AAV9) can cross the BBB by active-transport mechanism ((1) by receptor-mediated vesicular transport and (2) through tubular structures), while not compromising barrier integrity. Vesicular transport can end up in the nucleus (nu.) or on the basolateral side of the endothelial cells. Viral vectors that cannot pass through the BBB on its own (such as AAV2) can use the receptor-mediated route if the surface has been provided with a receptor for the ligand. Neither AAV9 nor AAV2 can pass between endothelial cells (3) because of the barrier of tight junctions (TJ).

If the vector itself cannot pass the $\mathrm{BBB}$, there are two alternative solutions: 1) get the vectors through after the transient disruption of tight junctions in the endothelial microvasculature, 2) or by receptor-mediated transcytosis [142].

With the transient disruption of the BBB (tight junctions), viral vectors are able to enter by paracellular transport into the CNS. This disruption can be accomplished by osomotically shrinking the cells of the BBB, for example, with high concentration of mannitol [143]. Mannitol does not penetrate the cell membrane and is quickly eliminated from the body by the kidney. This method has also been used for increasing the transport of chemotherapeutic drugs to treat brain tumors [156,157]. Mannitol-mediated osmotic disruption has been combined with viral vectors, such as adenovirus (Ad), herpesvirus, adeno-associated virus (AAV, AVV2 naturally does not cross the barrier), and SV40 [60,64,65]. McCarty and coworkers found that the right timing of vector delivery after mannitol infusion is crucial: The transduction of vectors can be up to 10 -fold more effective when administered $8 \mathrm{~min}$ after mannitol pre-treatment compared to $5 \mathrm{~min}$ or $10 \mathrm{~min}$ in mouse models [152]. 
SV40 vector was used in therapy for ALS with mannitol pretreatment, to transduce microglia in the CNS with higher efficiency and less systemic exposure [84].

The other BBB opening method is the magnetic resonance-guided focused ultrasound (FUS) with IV-administered microbubbles that can be used for more localized and concentrated vector transduction [158-160]. For more information about FUS and microbubbles, see Ultrasound and microbubbles paragraph.

Peptide vectors and shuttles. First, IgG was studied as a peptide shuttle, targeted against insulin and transferrin receptors [161] but was found to be unsuccessful due to its high affinity, which decreased the efficiency of the drug release [162,163]. Therefore, a variety of protein and peptide shuttles have been investigated, most of them are ligands of receptors on the brain endothelium or bioengineered designer peptides.

HIV virus trans-activator of transcription (TAT) peptide is the most used brain delivery peptide shuttle with high permeability across cell membranes [164]. The advantage of this shuttle is also its disadvantage; the easy penetration into any kind of cells makes it lacking brain selectivity. This problem seems to be solvable with combining TAT with higher selectivity receptor ligands, such as T7 peptide or transferrin (Tf) [160]. TAT is transported into the CNS by adsorptive-mediated transcytosis (AMT). AMT means all non-specific vesicular transport mechanisms that do not involve protein receptors. It is generally promoted by the interaction [165].

Cationized albumin was the first studied BBB shuttle [166]. As a drug delivery system, NP have many advantages but also some disadvantage too: It is an endogenous molecule, therefore, it is ensured that it has low toxicity. However, albumin has no brain specificity, but with different proteins conjugated to its surface the delivery through the BBB can be increased as well as its cell specificity, such as Apo E [167] or transferrin [168] specificity. But albumin also has the risk of transmitting blood-borne viral infection if it is derived from human blood, such as Abraxane do, so more attention is needed to produce this type of NP [84].

RVG29 was found during the study of neurotropism of the rabies virus, which is mediated by its glycoprotein (RVG) [169]. The unmodified peptide was shown to reach the brain. It was proved to be a potential gene delivery peptide shuttle: RVG transports oligonucleotides successfully into the brain to silence green fluorescence protein (GFP) in GFP-transgenic mice. RVG29 peptide shuttle uses nicotinic acetylcholine receptor to get through the BBB [170].

Low-density lipoprotein receptors (LDLRs) are the most exploited receptors for delivery across the BBB using peptides, because some of them are more expressed in the brain than in other organs [171] and overexpressed in some tumors [172]. LDLR targeting natural protein ligands, such as ApoB, ApoE fragments [173,174], and Angiopep-2, are widely used as a drug delivery peptide shuttle [170].

Angiopep-2 was discovered when the sequence of aprotinin was compared to other human proteins with Kunitz domain (that interacts with LRP1) with sequence alignment [175]. Angiopep-2 has been used to transport a wide variety of nanocarriers loaded with small molecules, proteins or genetic material into the CNS and is currently in clinical phase study as various types of anti-tumor medicines [170]. Apolipoprotein B100 (ApoB) is the main component of low-density lipoprotein, and it is a ligand of LRP2 [171]. Peptides that derived from ApoE showed higher efficiency in the transportation of other proteins $[174,176]$ because ApoE binds to a variety of LDLRs, including LRP1 [171]. These shuttles are transported by receptor-mediated transport (RMT). As for LDL receptors, LRP1 transporter mediates Angiopep-2 and ApoE, LRP2 and LDLR transport both ApoB and ApoE [170]. Glutathione (GSH), an endogenous peptide, was also investigated as a BBB shuttle after it was reported to be able to cross the BBB. There are many transporters in the CNS [177], that transport GSH and its conjugates [178].

Designed peptide shuttles. THR (named after the first three letters of its amino acid sequence) is obtained by phage display that interacts with transferrin receptor (TfR) but does not compete with Tf [179]. THR was successfully increased the transport of gold NPs coated with a peptide (LPFFD) and 
was capable to bind amyloid- $\beta$ and disrupt aggregates with the use of microwave irradiation [180]. THR also directly binds to AAV8 viral vector and facilitates its crossing through the BBB [181].

Phage display was also used to create Peptide-22 specific to LDLR and was tested to deliver chemotherapy for brain glioma treatment [182].

There are some designer BBB shuttles for small drugs (less than $300 \mathrm{Da}$ ), that consist of 2 to 4 amino acids and are able to cross the BBB through passive diffusion [170]. A big advantage of these small shuttles is that they minimize the loss of drug effectivity upon conjugation. Some examples are diketopiperazines [183], N-methylphenylalanines [184,185], and phenylprolines [186].

\subsection{Ultrasound and Microbubbles}

BBB can be disrupted with focused ultrasound (FUS) (Figure 8), but for more location specific drug delivery is combined with intravenously injected microbubbles (MBs), by widening interendothelial clefts and tight-junctions [187]. This method, also called as sonoporation, relies on the mechanical action of the gas MBs in ultrasonic pressure waves [188]. These MBs are about 1 to $10 \mathrm{um}$ in diameter with a lipid or protein shell, containing heavy gasses, which can be excreted by exhalation and make MBs more stable [188]. These particles also can be used as a drug delivery system by itself, for example, molecules can be attached to the shell [189-191] and they have also been used to deliver stem cells [192] and viral vectors $[158,160,193]$. Providing MBs with magnetic coating also can increase the effectivity of drug delivery by keeping them in the target area [194].

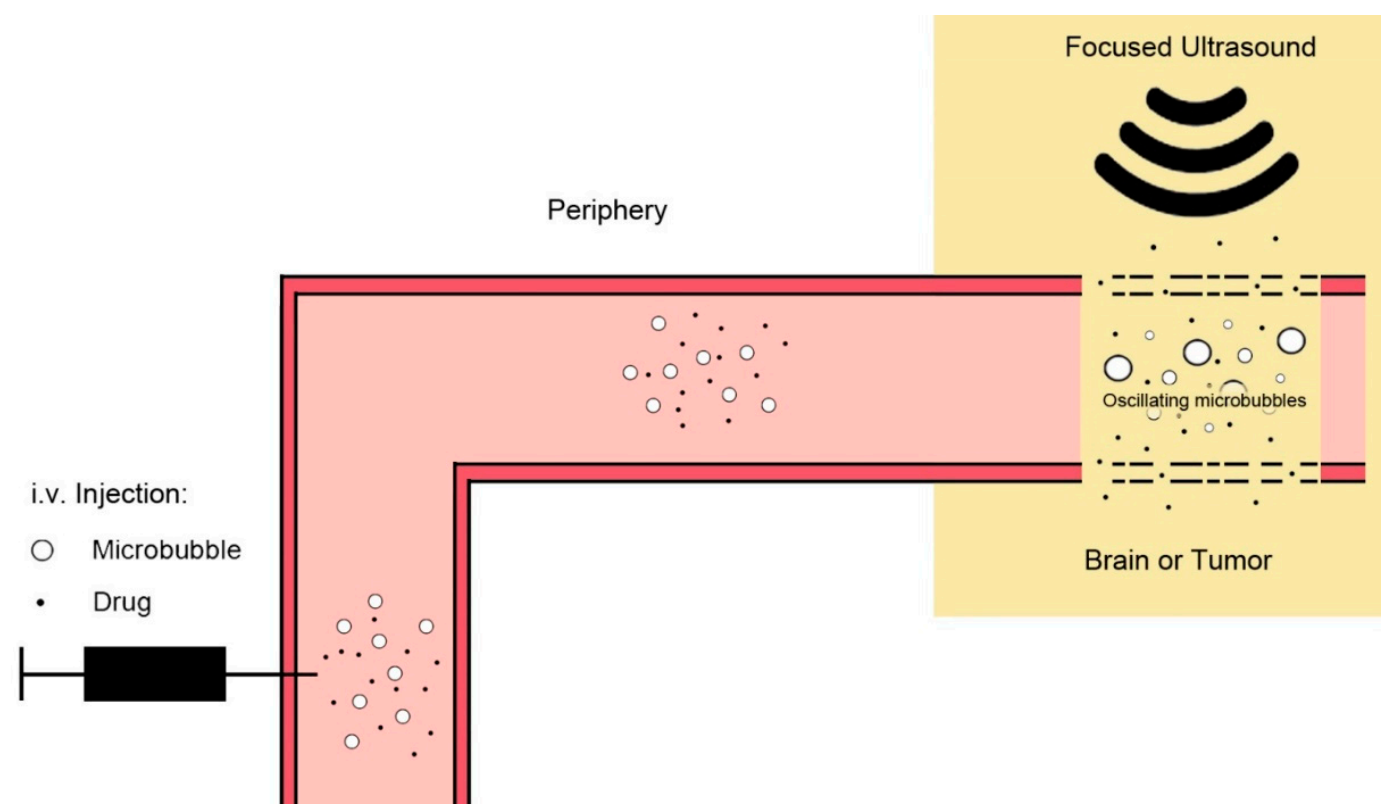

Figure 8. Sonoporation with Focused Ultrasound (FUS). Co-administration of drug or viral vectors with microbubbles is an effective way to delivery therapy into the brain or tumor. Even the peripheral exposure of the drug/vector can be avoided if they are conjugated onto the shell of the microbubbles. Moreover, magnetic microbubbles can be locked in the target area, maximizing the effectiveness of sonoporation.

Sonopermeation was defined by Snipstad and coworkers as the collective name for pore formation and other additional changes in the BBB permeability due to the microbubbles and ultrasound, such as the opening of tight junctions, stimulated endo- and transcytosis, enhanced perfusion, and stromal alterations [188]. This method has many advantages: 1) It can be focused just on the area of the tumor or diseased parts of the brain; 2) the poration does not require high energy ultrasound, therefore, does not cause damage in intermediery tissues; 3 ) however, the ultrasound can cause some overheating, just enough to increase blood flow $[187,195]$, vascular permeability $[196,197]$ that also modifies the 
effectiveness of drug delivery [198-201] in the target area, and 4) membrane integrity regenerates fast (within hours) after the intervention [202]. However, sonopermeation technique can cause some inflammation in the targeted area [203,204], but does not cause ischemia, neither apoptosis and does not damage neurons [205].

\subsection{Intranasal Drug Delivery}

Intranasally administered drugs can infiltrate the CNS through the olfactory or trigeminal routes by intracellular and extracellular pathways. In the intracellular route, the drug is taken up by olfactory or trigeminal sensory neurons which transmit to the olfactory bulb or to the pons. The extracellular route is between the supporting cells, where the drug is passing through the TJs, paracellular cleft, the lamina propria, perineural space, and then arrives at the subarachnoid space. Through the respiratory route, the drug molecules can reach the brainstem [206,207]. Intranasally administered drugs are distributed mainly in the distal areas of the CNS, besides the olfactory bulb or in the brainstem.

\subsection{Receptor-Mediated Opening}

Adenosine receptor (AR) substrates can modulate BBB permeability [208]. They can be used for enhanced drug delivery into the brain by activating A2A receptors or restricting the entry of neurotoxic agents or inflammatory immune cells into the brain [209]. This can occur in case of some diseases, such as stroke or sclerosis multiplex, by inhibiting AR activation [210].

Glutamate receptors can also modify the permeability of the BBB; N-methyl-D-aspartate (NMDA) receptor antagonists decrease the permeability. In addition, neuronal activation, using high-intensity magnetic stimulation, increases barrier permeability and facilitates drug delivery [211].

\subsection{Efflux Transporter Inhibition}

Inhibition of efflux transporters at the BBB can enhance the brain concentration of the substrate drugs which might lead to unwanted and serious CNS side effects from the compounds and also in other cases can provide a therapeutic advantage. However, the delivery of an anticonvulsant, encapsulated carbamazepine NPs was not affected by the inhibition of P-gp, because NPs circumvented the transporters of the BBB [212].

The CNS protective effect of BBB makes it quite difficult to treat brain malignancies or brain metastases, whereas the peripheral diseases are well controlled [213]. The CNS barrier can be partially overcome in the case of efflux transporter substrates by modulation of transporter proteins (e.g., P-gp or Mdr1).

A large number of animal studies, mostly working with Mdr1a/1b(-) knockout mice or dog breeds naturally lacking Mdr1 (e.g., Collie), concluded that the CNS:plasma ratio of the tested anticancer and antiretroviral drugs as well as the opioid loperamide or the calcium channel blocker verapamil can be increased up to 11-, 30-, 20-, and 9-fold, respectively [214-216]. These observations as well as many others which apply substrate-inhibitor combinations $[64,65]$ lead to the conclusion that P-gp has a vital role in preventing the entry of drugs into the CNS. Multidrug resistance proteins (MRPs) and breast cancer resistance protein (BCRP) were also detected on brain endothelial cells [217] and in human brain microvessels [218], respectively. The possibility of large clinical CNS drug interactions was raised under conditions when both multidrug resistance proten 1 (MDR1) and BCRP are inhibited. The phenomenon called 'P-gp and BCRP synergy' was described after unexpectedly high CNS accumulation of lapatinib, which was detected in Mdr1a/1b(-/-)-Bcrp double knockout mice, as compared with in the Mdr1a/1b(-/-) or Bcrp single knockouts [219]. The one order of magnitude higher exposure instead of the mathematical sum of the individual increases was later explained by Zamek-Gliszczynski and coworkers [220], namely that brain distribution of such drugs increases asymptotically as a function of the fraction excreted (fe), thus, the increase in exposure is not an additive parameter but a nonlinear function of fe. Although the CNS distribution of dual substrates 
can be very high in Mdr1a/1b(-/-) - Bcrp double knockout animals, the phenomenon can only occur at complete silencing of both efflux pumps.

\subsection{Direct Central Delivery}

Unfortunately for these days the invasive route is still the most efficent way to deliver potent drugs into the CNS in sufficent amount without too much peripheral exposure, which can cause toxic side effects. Intracerebral implantation is a traumatic procedure but in severe cases of chronic pain it has been utilized in a number of clinical trials. The implant consists of a biodegradable polymeric matrix or reservoir that contains the therapeutic agents [221]. The advantages of this procedure are sustained and controllable drug release. The skull has to be opened just when the reservoir is implanted, which is fully biocompatible and also the desired location of delivery can be controlled (where the implant is placed). However, the penetration of the drug is strongly dependent on the physicochemical characteristics of the drug, and the implant only can deliver a limited amount of the molecule (reload may be needed).

For example, BCNU (bis-chloroethylnitrosourea) (carmustine)-contained polyanhydride polymer wafer is used to treat recurrent high-grade gliomas [222]. With this matrix a 2-months-long drug release is possible. However, there is an increased risk of trauma and the delivery system is not that effective to warrant this price [223-225].

Intraparenchymal injection of viral vectors. For intraparenchymal injection of viral vectors it has been shown that all serotypes of AAV are capable of transducing expression in brain cells of various animals [226-229]. Furthermore, the different serotypes have preferences in cell types: AAV4 primarily targets ependymal cells [230], AAV8 tranduces astrocytes, microglia, and oligodendrocytes the most, and AAV9 had the greatest tropism for neurons [226].

Intraventricular/intrathecal/interstitial delivery. The most direct route to the CNS is to inject the drug into the intraventricular, intracavitary, or interstitial system. For example, intracerebroventricular (ICV) administration is considered as an intrathecal delivery via an ICV port implanted under the scalp of the patient and is used for treating various types of CNS diseases, such as infections [231,232], chronic pain $[233,234]$, and types of brain cancer [235]. This local delivery ensures high drug concentrations in the CNS while the peripheral exposure is minimal. Direct injections can provide a sufficient dose to treat, for example, primary brain tumors. Such drugs are nitrosourea and methotrexate, and have been used in various clinical trials with promising results. However, being invasive methods have the risk of infection [236].

Biological tissue delivery. The idea behind this technique is to implant fetal neural grafts into the dysfunctional area of the brain. This method was used in the treatment of Parkinson's disease [237]. However, these grafts do not survive for long due to a lack of neovascular innervation, but can be elongated with the proper technique of culturing distinct cell types [238].

\section{Summary}

The central nervous system is the most complex organ of the body. It directs our communication with the external world, what we do to our surroundings through our behaviors and what we perceive of our surroundings through our senses. The brain monitors and also controls our internal world, maintaining the balance among our internal organs that are necessary for our sustained life. Any of these functions may be affected by disease or injury. In unbalanced cases, it becomes necessary to consider how and where to deliver drugs to restore or improve the human condition. Our article attempted to summarize the various options to help drug delivery to the brain, to open the BBB or to make some tricks the overcome the barrier. To realize the theory behind the drug delivery concept, it is essential to account for the diverse structure, function, and physiology of the cerebral microvessels and the BBB.

Author Contributions: Anatomy, physiology, molecular basics of BBB (F.E.), BBB models (F.E.), strategies to improve delivery, figures, editing references (L.A.B.). 
Funding: The publication of this article has been partially supported by the European Union, co-financed by the European Social Fund (EFOP-3.6.3-VEKOP-16-2017-00002) and by the National Bionics Program of Hungary.

Conflicts of Interest: The authors declare no conflict of interest.

\section{References}

1. Pardridge, W.M. Drug targeting to the brain. Pharm. Res. 1993, 24, 1733-1744. [CrossRef] [PubMed]

2. Pardridge, W. CNS drug design based on principles of blood-brain barrier transport. J. Neurochem. 1998, 70, 1781-1792. [CrossRef] [PubMed]

3. Abbott, N.J.; Patabendige, A.A.K.; Dolman, D.E.M.; Yusof, S.R.; Begley, D.J. Structure and function of the blood-brain barrier. Neurobiol. Dis. 2010, 38, 1-15. [CrossRef] [PubMed]

4. Sedlakova, R.; Shivers, R.R.; Del Maestro, R.F. Ultrastructure of the blood-brain barrier in the rabbit. J. Submicrosc. Cytol. Pathol. 1999, 31, 149-161. [PubMed]

5. Redzic, Z. Molecular biology of the blood-brain and the blood-cerebrospinal fluid barriers: Similarities and differences. Fluids Barriers CNS 2011, 8, 3. [CrossRef] [PubMed]

6. De Bock, M.; Van Haver, V.; Vandenbroucke, R.E.; Decrock, E.; Wang, N.; Leybaert, L. Into rather unexplored terrain-transcellular transport across the blood-brain barrier. Glia 2016, 64, 1097-1123. [CrossRef] [PubMed]

7. De Bock, M.; Vandenbroucke, R.E.; Decrock, E.; Culot, M.; Cecchelli, R.; Leybaert, L. A new angle on blood-CNS interfaces: A role for connexins? FEBS Lett. 2014, 588, 1259-1270. [CrossRef] [PubMed]

8. Hawkins, B.T.; Davis, T.P. The Blood-Brain Barrier/Neurovascular Unit in Health and Disease. Pharmacol. Rev. 2005, 57, 173-185. [CrossRef] [PubMed]

9. Crone, C. Electrical resistance of a capillary endothelium. J. Gen. Physiol. 1981, 77, 349-371. [CrossRef] [PubMed]

10. Gorlé, N.; Van Cauwenberghe, C.; Libert, C.; Vandenbroucke, R.E. The effect of aging on brain barriers and the consequences for Alzheimer's disease development. Mamm. Genome 2016, 27, 407-420. [CrossRef] [PubMed]

11. Oldendorf, W.H.; Cornford, M.E.; Brown, W.J. The large apparent work capability of the blood-brain barrier: A study of the mitochondrial content of capillary endothelial cells in brain and other tissues of the rat. Ann. Neurol. 1977, 1, 409-417. [CrossRef] [PubMed]

12. Sanchez-Covarrubias, L.; Slosky, L.; Thompson, B.; Davis, T.; Ronaldson, P. Transporters at CNS Barrier Sites: Obstacles or Opportunities for Drug Delivery? Curr. Pharm. Des. 2014, 20, 1422-1449. [CrossRef] [PubMed]

13. Fenstermacher, J.; Gross, P.; Sposito, N.; Acuff, V.; Pettersen, S.; Gruber, K. Structural and Functional Variations in Capillary Systems within the Brain. Ann. N. Y. Acad. Sci. 1988, 529, 21-30. [CrossRef] [PubMed]

14. Takakura, Y.; Audus, K.L.; Borchardt, R.T. Blood-Brain Barrier: Transport Studies in Isolated Brain Capillaries and in Cultured Brain Endothelial Cells. Adv. Pharmacol. 1991, 22, 137-165. [PubMed]

15. Vorbrodt, A.W.; Dobrogowska, D.H. Molecular anatomy of intercellular junctions in brain endothelial and epithelial barriers: Electron microscopist's view. Brain Res. Rev. 2003, 42, 221-242. [CrossRef]

16. Rodríguez-Arellano, J.J.; Parpura, V.; Zorec, R.; Verkhratsky, A. Astrocytes in physiological aging and Alzheimer's disease. Neuroscience 2016, 323, 170-182. [CrossRef] [PubMed]

17. Abbott, N.J.; Rönnbäck, L.; Hansson, E. Astrocyte-endothelial interactions at the blood-brain barrier. Nat. Rev. Neurosci. 2006, 7, 41-53. [CrossRef] [PubMed]

18. De Lange, E.; Bajza, Á.; Imre, P.; Csorba, A.; Dénes, L.; Erdő, F. Maturation, barrier function, aging and breakdown of the blood-brain barrier. In Aging: Exploring a Complex Phenomenon; Ahmad, S.I., Ed.; CRC Press: Boca Raton, FL, USA, 2018; p. 271.

19. Kettenmann, H.; Hanisch, U.-K.; Noda, M.; Verkhratsky, A. Physiology of Microglia. Physiol. Rev. 2011, 91, 461-553. [CrossRef] [PubMed]

20. Kofler, J.; Wiley, C.A. Microglia:Key Innate Immune Cells of the Brain. Toxicol. Pathol. 2011, 39, $103-114$. [CrossRef] [PubMed]

21. Harry, G.J. Microglia during development and aging. Pharmacol. Ther. 2013, 139, 313-326. [CrossRef] [PubMed]

22. Huber, J.D.; Campos, C.R.; Mark, K.S.; Davis, T.P. Alterations in blood-brain barrier ICAM-1 expression and brain microglial activation after $\lambda$-carrageenan-induced inflammatory pain. Am. J. Physiol. Circ. Physiol. 2006, 290, H732-H740. [CrossRef] [PubMed] 
23. Abbott, N.J.; Dolman, D.E.M.; Yusof, S.R.; Reichel, A. In vitro models of CNS barriers. In Drug Delivery to the Brain; Hammarlund-Udenaes, M., de Lange, E.C.M., Thorne, R.G., Eds.; 2014; ISBN 978-1-4614-9104-0.

24. Wilhelm, I.; Krizbai, I.A. In vitro models of the blood-brain barrier for the study of drug delivery to the brain. Mol. Pharm. 2014, 11, 1949-1963. [CrossRef] [PubMed]

25. Eigenmann, D.E.; Xue, G.; Kim, K.S.; Moses, A.V.; Hamburger, M.; Oufir, M. Comparative study of four immortalized human brain capillary endothelial cell lines, hCMEC/D3, hBMEC, TY10, and BB19, and optimization of culture conditions, for an in vitro blood-brain barrier model for drug permeability studies. Fluids Barriers CNS 2013, 10, 33. [CrossRef] [PubMed]

26. Sivandzade, F.; Cucullo, L. In-vitro blood-brain barrier modeling: A review of modern and fast-advancing technologies. J. Cereb. Blood Flow Metab. 2018, 38, 1667-1681. [CrossRef] [PubMed]

27. Branca, J.J.V.; Maresca, M.; Morucci, G.; Becatti, M.; Paternostro, F.; Gulisano, M.; Ghelardini, C.; Salvemini, D.; Di Cesare Mannelli, L.; Pacini, A. Oxaliplatin-induced blood brain barrier loosening: A new point of view on chemotherapy-induced neurotoxicity. Oncotarget 2018, 9, 23426-23438. [PubMed]

28. Kuroda, H.; Tachikawa, M.; Yagi, Y.; Umetsu, M.; Nurdin, A.; Miyauchi, E.; Watanabe, M.; Uchida, Y.; Terasaki, T. Cluster of Differentiation 46 Is the Major Receptor in Human Blood-Brain Barrier Endothelial Cells for Uptake of Exosomes Derived from Brain-Metastatic Melanoma Cells (SK-Mel-28). Mol. Pharm. 2018, 16, 292-304. [CrossRef] [PubMed]

29. Mizutani, T.; Ishizaka, A.; Nihei, C.I. Transferrin Receptor 1 Facilitates Poliovirus Permeation of Mouse Brain Capillary Endothelial Cells. J. Biol. Chem. 2016, 291, 2829-2836. [CrossRef] [PubMed]

30. Zhou, Q.; Wang, Y.W.; Ni, P.F.; Chen, Y.N.; Dong, H.Q.; Qian, Y.N. Effect of tryptase on mouse brain microvascular endothelial cells via protease-activated receptor 2. J. Neuroinflamm. 2018, 15, 248. [CrossRef] [PubMed]

31. Kinoshita, Y.; Nogami, K.; Jomura, R.; Akanuma, S.I.; Abe, H.; Inouye, M.; Kubo, Y.; Hosoya, K.I. Investigation of Receptor-Mediated Cyanocobalamin (Vitamin B12) Transport across the Inner Blood-Retinal Barrier Using Fluorescence-Labeled Cyanocobalamin. Mol. Pharm. 2018, 15, 3583-3594. [CrossRef] [PubMed]

32. Motta, C.; D’Angeli, F.; Scalia, M.; Satriano, C.; Barbagallo, D.; Naletova, I.; Anfuso, C.D.; Lupo, G.; Spina-Purrello, V. PJ-34 inhibits PARP-1 expression and ERK phosphorylation in glioma-conditioned brain microvascular endothelial cells. Eur. J. Pharmacol. 2015, 761, 55-64. [CrossRef] [PubMed]

33. Suzuki, T.; Aoyama, T.; Suzuki, N.; Kobayashi, M.; Fukami, T.; Matsumoto, Y.; Tomono, K. Involvement of a proton-coupled organic cation antiporter in the blood-brain barrier transport of amantadine. Biopharm. Drug Dispos. 2016, 37, 323-335. [CrossRef] [PubMed]

34. Tega, Y.; Yamazaki, Y.; Akanuma, S.I.; Kubo, Y.; Hosoya, K.I. Impact of Nicotine Transport across the Blood-Brain Barrier: Carrier-Mediated Transport of Nicotine and Interaction with Central Nervous System Drugs. Biol. Pharm. Bull. 2018, 41, 1330-1336. [CrossRef] [PubMed]

35. Ishisaka, A.; Mukai, R.; Terao, J.; Shibata, N.; Kawai, Y. Specific localization of quercetin-3-O-glucuronide in human brain. Arch. Biochem. Biophys. 2014, 557, 11-17. [CrossRef] [PubMed]

36. Blecharz-Lang, K.G.; Wagner, J.; Fries, A.; Nieminen-Kelhä, M.; Rösner, J.; Schneider, U.C.; Vajkoczy, P. Interleukin 6-Mediated Endothelial Barrier Disturbances Can Be Attenuated by Blockade of the IL6 Receptor Expressed in Brain Microvascular Endothelial Cells. Transl. Stroke Res. 2018, 9, 631-642. [CrossRef] [PubMed]

37. Zuccolo, E.; Lim, D.; Kheder, D.A.; Perna, A.; Catarsi, P.; Botta, L.; Rosti, V.; Riboni, L.; Sancini, G.; Tanzi, F.; et al. Acetylcholine induces intracellular $\mathrm{Ca} 2+$ oscillations and nitric oxide release in mouse brain endothelial cells. Cell Calcium 2017, 66, 33-47. [CrossRef] [PubMed]

38. Dasgupta, S.; Wang, G.; Yu, R.K. Sulfoglucuronosyl paragloboside promotes endothelial cell apoptosis in inflammation: Elucidation of a novel glycosphingolipid-signaling pathway. J. Neurochem. 2011, 119, 749-759. [CrossRef] [PubMed]

39. El-Andaloussi, S.; Lee, Y.; Lakhal-Littleton, S.; Li, J.; Seow, Y.; Gardiner, C.; Alvarez-Erviti, L.; Sargent, I.L.; Wood, M.J.A. Exosome-mediated delivery of siRNA in vitro and in vivo. Nat. Protoc. 2012, 7, 2112-2126. [CrossRef] [PubMed]

40. Wolburg, H.; Neuhaus, J.; Kniesel, U.; Krauss, B.; Schmid, E.M.; Ocalan, M.; Farrell, C.; Risau, W. Modulation of tight junction structure in blood-brain barrier endothelial cells. Effects of tissue culture, second messengers and cocultured astrocytes. J. Cell Sci. 1994, 107, 1347-1357. [PubMed] 
41. Gaillard, P.J.; Van Der Sandt, I.C.J.; Voorwinden, L.H.; Vu, D.; Nielsen, J.L.; De Boer, A.G.; Breimer, D.D. Astrocytes increase the functional expression of P-glycoprotein in an in vitro model of the blood-brain barrier. Pharm. Res. 2000, 17, 1198-1205. [CrossRef] [PubMed]

42. Hori, S.; Ohtsuki, S.; Tachikawa, M.; Kimura, N.; Kondo, T.; Watanabe, M.; Nakashima, E.; Terasaki, T. Functional expression of rat ABCG2 on the luminal side of brain capillaries and its enhancement by astrocyte-derived soluble factor(s). J. Neurochem. 2004, 90, 526-536. [CrossRef] [PubMed]

43. Sá-Pereira, I.; Brites, D.; Brito, M.A. Neurovascular unit: A focus on pericytes. Mol. Neurobiol. 2012, 45, 327-347. [CrossRef] [PubMed]

44. Yamanaka, S.; Blau, H.M. Nuclear reprogramming to a pluripotent state by three approaches. Nature 2010, 465, 704. [CrossRef] [PubMed]

45. Dekmak, A.S.; Mantash, S.; Shaito, A.; Toutonji, A.; Ramadan, N.; Ghazale, H.; Kassem, N.; Darwish, H.; Zibara, K. Stem cells and combination therapy for the treatment of traumatic brain injury. Behav. Brain Res. 2018, 340, 49-62. [CrossRef] [PubMed]

46. Barkho, B.Z.; Zhao, X. Adult Neural Stem Cells: Response to Stroke Injury. Curr. Stem Cell Res. Ther. 2011, 6, 327-338. [CrossRef] [PubMed]

47. Tian, X.; Brookes, O.; Battaglia, G. Pericytes from Mesenchymal Stem Cells as a model for the blood-brain barrier. Sci. Rep. 2017, 7, 39676. [CrossRef] [PubMed]

48. Crisan, M.; Yap, S.; Casteilla, L.; Chen, C.W.; Corselli, M.; Park, T.S.; Andriolo, G.; Sun, B.; Zheng, B.; Zhang, L.; et al. A Perivascular Origin for Mesenchymal Stem Cells in Multiple Human Organs. Cell Stem Cell 2008, 3, 301-313. [CrossRef] [PubMed]

49. Naik, P.; Cucullo, L. In vitro blood-brain barrier models: Current and perspective technologies. J. Pharm. Sci. 2012, 101, 1337-1354. [CrossRef] [PubMed]

50. Nakagawa, S.; Deli, M.A.; Kawaguchi, H.; Shimizudani, T.; Shimono, T.; Kittel, A.; Tanaka, K.; Niwa, M. A new blood-brain barrier model using primary rat brain endothelial cells, pericytes and astrocytes. Neurochem. Int. 2009, 54, 253-263. [CrossRef] [PubMed]

51. Toyoda, K.; Tanaka, K.; Nakagawa, S.; Thuy, D.H.; Ujifuku, K.; Kamada, K.; Hayashi, K.; Matsuo, T.; Nagata, I.; Niwa, M. Initial contact of glioblastoma cells with existing normal brain endothelial cells strengthen the barrier function via fibroblast growth factor 2 secretion: a new in vitro blood-brain barrier model. Cell. Mol. Neurobiol. 2013, 33, 489-501. [CrossRef] [PubMed]

52. Xue, Q.; Liu, Y.; Qi, H.; Ma, Q.; Xu, L.; Chen, W.; Chen, G.; Xu, X. A novel brain neurovascular unit model with neurons, astrocytes and microvascular endothelial cells of rat. Int. J. Biol. Sci. 2013, 9, 174-189. [CrossRef] [PubMed]

53. Vandenhaute, E.; Dehouck, L.; Boucau, M.C.; Sevin, E.; Uzbekov, R.; Tardivel, M.; Gosselet, F.; Fenart, L.; Cecchelli, R.; Dehouck, M.P. Modelling the neurovascular unit and the blood-brain barrier with the unique function of pericytes. Curr. Neurovasc. Res. 2011, 8, 258-269. [CrossRef] [PubMed]

54. Lippmann, E.S.; Weidenfeller, C.; Svendsen, C.N.; Shusta, E.V. Blood-brain barrier modeling with co-cultured neural progenitor cell-derived astrocytes and neurons. J. Neurochem. 2011, 119, 507-520. [PubMed]

55. Helms, H.C.; Abbott, N.J.; Burek, M.; Cecchelli, R.; Couraud, P.O.; Deli, M.A.; Förster, C.; Galla, H.J.; Romero, I.A.; Shusta, E.V.; et al. In vitro models of the blood-brain barrier: An overview of commonly used brain endothelial cell culture models and guidelines for their use. J. Cereb. Blood Flow Metab. 2015, 36, 862-890. [CrossRef] [PubMed]

56. Yeon, J.H.; Na, D.; Choi, K.; Ryu, S.W.; Choi, C.; Park, J.K. Reliable permeability assay system in a microfluidic device mimicking cerebral vasculatures. Biomed. Microdevices 2012, 14, 1141-1148. [CrossRef] [PubMed]

57. Brigitte Esch, M.; Hwan Sung, J.; Yang, J.; Yu, C.; Yu, J.; March, J.C.; Louis Shuler, M. On chip porous polymer membranes for integration of gastrointestinal tract epithelium with microfluidic "body-on-a-chip" devices. Biomed. Microdevices 2012, 14, 895-906. [CrossRef] [PubMed]

58. Griep, L.M.; Wolbers, F.; De Wagenaar, B.; Ter Braak, P.M.; Weksler, B.B.; Romero, I.A.; Couraud, P.O.; Vermes, I.; Van Der Meer, A.D.; Van Den Berg, A. BBB on CHIP: Microfluidic platform to mechanically and biochemically modulate blood-brain barrier function. Biomed. Microdevices 2013, 15, 145-150. [CrossRef] [PubMed]

59. Booth, R.; Kim, H. Characterization of a microfluidic in vitro model of the blood-brain barrier $(\mu \mathrm{BBB})$. Lab Chip 2012, 12, 1784-1792. [CrossRef] [PubMed] 
60. Bhatia, S.N.; Ingber, D.E. Microfluidic organs-on-chips. Nat. Biotechnol. 2014, 32, 760-772. [CrossRef] [PubMed]

61. Hammarlund-Udenaes, M.; Fridén, M.; Syvänen, S.; Gupta, A. On the rate and extent of drug delivery to the brain. Pharm. Res. 2008, 25, 1737-1750. [CrossRef] [PubMed]

62. Liu, X.; Chen, C.; Smith, B.J. Progress in Brain Penetration Evaluation in Drug Discovery and Development. J. Pharmacol. Exp. Ther. 2008, 325, 349-356. [CrossRef] [PubMed]

63. De Lange, E.C.M.; Danhof, M.; De Boer, A.G.; Breimer, D.D. Methodological considerations of intracerebral microdialysis in pharmacokinetic studies on drug transport across the blood-brain barrier. Brain Res. Rev. 1997, 25, 27-49. [CrossRef]

64. Sziráki, I.; Erdo, F.; Beéry, E.; Molnár, P.M.; Fazakas, C.; Wilhelm, I.; Makai, I.; Kis, E.; Herédi-Szabó, K.; Abonyi, T.; et al. Quinidine as an abcb1 probe for testing drug interactions at the blood-brain barrier: An in vitro in vivo correlation study. J. Biomol. Screen. 2011, 16, 886-894. [CrossRef] [PubMed]

65. Sziráki, I.; Erdo, F.; Trampus, P.; Sike, M.; Molnár, P.M.; Rajnai, Z.; Molnár, J.; Wilhelm, I.; Fazakas, C.; Kis, E.; et al. The use of microdialysis techniques in mice to study P-gp function at the blood-brain barrier. J. Biomol. Screen. 2013, 18, 430-440. [CrossRef] [PubMed]

66. Wainwright, D.A.; Horbinski, C.M.; Hashizume, R.; James, C.D. Therapeutic Hypothesis Testing With Rodent Brain Tumor Models. Neurotherapeutics 2017, 14, 385-392. [CrossRef] [PubMed]

67. Gutmann, D.H.; Stiles, C.D.; Lowe, S.W.; Bollag, G.E.; Furnari, F.B.; Charest, A. Report from the fifth national cancer institute mouse models of human cancers consortium nervous system tumors workshop. Neuro Oncol. 2011, 13, 692-699. [CrossRef] [PubMed]

68. Raucher, D.; Dragojevic, S.; Ryu, J. Macromolecular Drug Carriers for Targeted Glioblastoma Therapy: Preclinical Studies, Challenges, and Future Perspectives. Front. Oncol. 2018, 8, 624. [CrossRef] [PubMed]

69. Smith, Q.R.; Samala, R. In situ and in vivo animal models. In Drug Delivery to the Brain: Physiological Concepts, Methodologies and Approaches; Hammarlund-Udenaes, M., de Lange, E.C.M., Thorne, R.G., Eds.; Springer: Berlin/Heidelberg, Germany, 2014; pp. 199-213, ISBN 978-1-4614-9104-0.

70. Hoshyar, N.; Gray, S.; Han, H.; Bao, G. The effect of nanoparticle size on in vivo pharmacokinetics and cellular interaction. Nanomedicine 2016, 11, 673-692. [CrossRef] [PubMed]

71. Yuan, F.; Griffith, L.; Jain, R.K.; Torchilin, V.P.; Roberts, W.G.; Hobbs, S.K.; Monsky, W.L. Regulation of transport pathways in tumor vessels: Role of tumor type and microenvironment. Proc. Natl. Acad. Sci. USA 2002, 95, 4607-4612.

72. Kang, J.H.; Cho, J.; Ko, Y.T. Investigation on the effect of nanoparticle size on the blood-brain tumour barrier permeability by in situ perfusion via internal carotid artery in mice. J. Drug Target. 2019, 27, $103-110$. [CrossRef] [PubMed]

73. Betzer, O.; Shilo, M.; Opochinsky, R.; Barnoy, E.; Motiei, M.; Okun, E.; Yadid, G.; Popovtzer, R. The effect of nanoparticle size on the ability to cross the blood-brain barrier: An in vivo study. Nanomedicine 2017, 12, 1533-1546. [CrossRef] [PubMed]

74. Bertrand, N.; Leroux, J.C. The journey of a drug-carrier in the body: An anatomo-physiological perspective. J. Control. Release 2012, 161, 152-163. [CrossRef] [PubMed]

75. Hagens, W.I.; Geertsma, R.E.; Burger, M.C.; De Jong, W.H.; Krystek, P.; Sips, A.J.A.M. Particle size-dependent organ distribution of gold nanoparticles after intravenous administration. Biomaterials 2008, 29, 1912-1919.

76. Kajino, K.; Kawaguchi, A.; Ijiro, K.; Ninomiya, T.; Matsunaga, T.; Yamaguchi, H.; Orba, Y.; Kobayashi, S.; Sawa, H.; Niikura, K.; et al. Gold Nanoparticles as a Vaccine Platform: Influence of Size and Shape on Immunological Responses in Vitro and in Vivo. ACS Nano 2013, 7, 3926-3938.

77. Madden, V.J.; Napier, M.E.; Luft, J.C.; Ropp, P.A.; Pohlhaus, P.D.; Gratton, S.E.A.; DeSimone, J.M. The effect of particle design on cellular internalization pathways. Proc. Natl. Acad. Sci. USA 2008, 105, 11613-11618.

78. Szejtli, J. Cyclodextrin Technology. In Topics in Inclusion Science; 1988; ISBN 90-277-2314-1.

79. Vecsernyés, M.; Fenyvesi, F.; Bácskay, I.; Deli, M.A.; Szente, L.; Fenyvesi, É. Cyclodextrins, Blood-Brain Barrier, and Treatment of Neurological Diseases. Arch. Med. Res. 2014, 45, 711-729. [CrossRef] [PubMed]

80. Ohtani, Y.; Irie, T.; Uekama, K.; Fukunaga, K.; Pitha, J. Differential effects of $\alpha$-, $\beta$ - and $\gamma$-cyclodextrins on human erythrocytes. Eur. J. Biochem. 1989, 186, 17-22. [CrossRef] [PubMed]

81. Monnaert, V.; Tilloy, S.; Bricout, H.; Fenart, L.; Cecchelli, R.; Monflier, E. Behavior of $\alpha_{-}^{-}, \beta_{-}^{-}$, and $\gamma$-cyclodextrins and their derivatives on an in vitro model of blood-brain barrier. J. Pharmacol. Exp. Ther. 2004, 310, 745-751. [CrossRef] [PubMed] 
82. Binkowski-Machut, C.; Hapiot, F.; Martin, P.; Cecchelli, R.; Monflier, E. How cyclodextrins can mask their toxic effect on the blood-brain barrier. Bioorg. Med. Chem. Lett. 2006, 16, 1784-1787. [CrossRef] [PubMed]

83. Tilloy, S.; Monnaert, V.; Fenart, L.; Bricout, H.; Cecchelli, R.; Monflier, E. Methylated $\beta$-cyclodextrin as P-gp modulators for deliverance of doxorubicin across an in vitro model of blood-brain barrier. Bioorg. Med. Chem. Lett. 2006, 16, 2154-2157. [CrossRef] [PubMed]

84. Hammarlund-Udenaes, M.; de Lange, E.C.M.; Thorne, R.G. (Eds.) Drug Delivery to the Brain; Springer: Berlin/Heidelberg, Germany, 2014.

85. Rip, J. Liposome technologies and drug delivery to the CNS. Drug Discov. Today Technol. 2016, $20,53-58$. [CrossRef] [PubMed]

86. Noble, G.T.; Stefanick, J.F.; Ashley, J.D.; Kiziltepe, T.; Bilgicer, B. Ligand-targeted liposome design: Challenges and fundamental considerations. Trends Biotechnol. 2014, 32, 32-45. [CrossRef] [PubMed]

87. De la Torre, C.; Ceña, V. The delivery challenge in neurodegenerative disorders: The nanoparticles role in alzheimer's disease therapeutics and diagnostics. Pharmaceutics 2018, 10, 190. [CrossRef] [PubMed]

88. Vieira, D.B.; Gamarra, L.F. Getting into the brain: Liposome-based strategies for effective drug delivery across the blood-brain barrier. Int. J. Nanomed. 2016, 11, 5381-5414. [CrossRef] [PubMed]

89. Song, Q.; Song, H.; Xu, J.; Huang, J.; Hu, M.; Gu, X.; Chen, J.; Zheng, G.; Chen, H.; Gao, X. Biomimetic ApoE-reconstituted high density lipoprotein nanocarrier for blood-brain barrier penetration and amyloid beta-targeting drug delivery. Mol. Pharm. 2016, 13, 3976-3987. [CrossRef] [PubMed]

90. Hauser, P.S.; Narayanaswami, V.; Ryan, R.O. Apolipoprotein E: From lipid transport to neurobiology. Prog. Lipid Res. 2011, 50, 62-74. [CrossRef] [PubMed]

91. Holtzman, D.M.; Herz, J.; Bu, G. Apolipoprotein E and apolipoprotein E receptors: Normal biology and roles in Alzheimer disease. Cold Spring Harb. Perspect. Med. 2012, 2, a006312. [CrossRef] [PubMed]

92. Raub, T.J.; Audus, K.L. Adsorptive Endocytosis and Membrane Recycling by Cultured Primary Bovine Brain Microvessel Endothelial-Cell Monolayers. J. Cell Sci. 1990, 97, 127-138. [PubMed]

93. Van Dommelen, S.M.; Vader, P.; Lakhal, S.; Kooijmans, S.A.A.; Van Solinge, W.W.; Wood, M.J.A.; Schiffelers, R.M. Microvesicles and exosomes: Opportunities for cell-derived membrane vesicles in drug delivery. J. Control. Release 2012, 161, 635-644. [CrossRef] [PubMed]

94. Sun, D.; Zhuang, X.; Zhang, S.; Deng, Z.B.; Grizzle, W.; Miller, D.; Zhang, H.G. Exosomes are endogenous nanoparticles that can deliver biological information between cells. Adv. Drug Deliv. Rev. 2013, 65, 342-347. [CrossRef] [PubMed]

95. Théry, C.; Ostrowski, M.; Segura, E. Membrane vesicles as conveyors of immune responses. Nat. Rev. Immunol. 2009, 9, 581-593. [CrossRef] [PubMed]

96. Yang, T.; Martin, P.; Fogarty, B.; Brown, A.; Schurman, K.; Phipps, R.; Yin, V.P.; Lockman, P.; Bai, S. Exosome delivered anticancer drugs across the blood-brain barrier for brain cancer therapy in Danio Rerio. Pharm. Res. 2015, 32, 2003-2014. [CrossRef] [PubMed]

97. Yang, T.; Fogarty, B.; LaForge, B.; Aziz, S.; Pham, T.; Lai, L.; Bai, S. Delivery of Small Interfering RNA to Inhibit Vascular Endothelial Growth Factor in Zebrafish Using Natural Brain Endothelia Cell-Secreted Exosome Nanovesicles for the Treatment of Brain Cancer. AAPS J. 2017, 19, 475-486. [CrossRef] [PubMed]

98. Li, T.; Yang, J.; Liu, R.; Yi, Y.; Huang, M.; Wu, Y.; Tu, H.; Zhang, L. Efficient fabrication of reversible $\mathrm{pH}$-induced carboxymethyl chitosan nanoparticles for antitumor drug delivery under weakly acidic microenvironment. Int. J. Biol. Macromol. 2018, 126, 68-73. [CrossRef] [PubMed]

99. Kurakhmaeva, K.B.; Djindjikhashvili, I.A.; Petrov, V.E.; Balabanyan, V.U.; Voronina, T.A.; Trofimov, S.S.; Kreuter, J.; Gelperina, S.; Begley, D.; Alyautdin, R.N. Brain targeting of nerve growth factor using poly(butyl cyanoacrylate) nanoparticles. J. Drug Target. 2009, 17, 564-574. [CrossRef] [PubMed]

100. Eslami, M.; Nikkhah, S.J.; Hashemianzadeh, S.M.; Sajadi, S.A.S. The compatibility of Tacrine molecule with poly(n-butylcyanoacrylate) and Chitosan as efficient carriers for drug delivery: A molecular dynamics study. Eur. J. Pharm. Sci. 2016, 82, 79-85. [CrossRef] [PubMed]

101. Pérez-Martínez, F.C.; Guerra, J.; Posadas, I.; Ceña, V. Barriers to non-viral vector-mediated gene delivery in the nervous system. Pharm. Res. 2011, 28, 1843-1858. [CrossRef] [PubMed]

102. Klementieva, O.; Aso, E.; Filippini, D.; Benseny-Cases, N.; Carmona, M.; Juves, S.; Appelhans, D.; Cladera, J.; Ferrer, I. Effect of poly(propylene imine) glycodendrimers on beta-amyloid aggregation in vitro and in APP/PS1 transgenic mice, as a model of brain amyloid deposition and Alzheimer's disease. Biomacromolecules 2013, 14, 3570-3580. [CrossRef] [PubMed] 
103. Sheikhpour, M.; Barani, L.; Kasaeian, A. Biomimetics in drug delivery systems: A critical review. J. Control. Release 2017, 253, 97-109. [CrossRef] [PubMed]

104. Santos, S.D.; Xavier, M.; Leite, D.M.; Moreira, D.A.; Custódio, B.; Torrado, M.; Castro, R.; Leiro, V.; Rodrigues, J.; Tomás, H.; et al. PAMAM dendrimers: Blood-brain barrier transport and neuronal uptake after focal brain ischemia. J. Control. Release 2018, 291, 65-79. [CrossRef] [PubMed]

105. Wasiak, T.; Ionov, M.; Nieznanski, K.; Nieznanska, H.; Klementieva, O.; Granell, M.; Cladera, J.; Majoral, J.P.; Caminade, A.M.; Klajnert, B. Phosphorus dendrimers affect Alzheimer's (A $\beta$ 1-28) peptide and MAP-Tau protein aggregation. Mol. Pharm. 2012, 9, 458-469. [CrossRef] [PubMed]

106. Fülöp, L.; Mándity, I.M.; Juhász, G.; Szegedi, V.; Hetényi, A.; Wéber, E.; Bozsó, Z.; Simon, D.; Benko, M.; Király, Z.; et al. A foldamer-dendrimer conjugate neutralizes synaptotoxic $\beta$-amyloid oligomers. PLoS ONE 2012, 7, e39485. [CrossRef] [PubMed]

107. Dilnawaz, F.; Sahoo, S.K. Therapeutic approaches of magnetic nanoparticles for the central nervous system. Drug Discov. Today 2015, 20, 1256-1264. [CrossRef] [PubMed]

108. Fang, C.; Zhang, M. Multifunctional magnetic nanoparticles for medical imaging applications. J. Mater. Chem. 2009, 19, 6258-6266. [CrossRef] [PubMed]

109. Akbarzadeh, A.; Samiei, M.; Davaran, S. Magnetic nanoparticles: Preparation, physical properties, and applications in biomedicine. Nanoscale Res. Lett. 2012, 7, 144. [CrossRef] [PubMed]

110. Velasco-Aguirre, C.; Morales, F.; Gallardo-Toledo, E.; Guerrero, S.; Giralt, E.; Araya, E.; Kogan, M.J. Peptides and proteins used to enhance gold nanoparticle delivery to the brain: Preclinical approaches. Int. J. Nanomed. 2015, 10, 4919-4936.

111. Sela, H.; Cohen, H.; Elia, P.; Zach, R.; Karpas, Z.; Zeiri, Y. Spontaneous penetration of gold nanoparticles through the blood brain barrier (BBB). J. Nanobiotechnol. 2015, 13, 71. [CrossRef] [PubMed]

112. Zhang, Y.; Walker, J.B.; Minic, Z.; Liu, F.; Goshgarian, H.; Mao, G. Transporter protein and drug-conjugated gold nanoparticles capable of bypassing the blood-brain barrier. Sci. Rep. 2016, 6, 25794. [CrossRef] [PubMed]

113. Cole, L.E.; Ross, R.D.; Tilley, J.M.; Vargo-Gogola, T.; Roeder, R.K. Gold nanoparticles as contrast agents in $\mathrm{X}$-ray imaging and computed tomography. Nanomedicine 2015, 10, 321-341. [CrossRef] [PubMed]

114. Wilson, C.M.; Magnaudeix, A.; Naves, T.; Vincent, F.; Lalloue, F.; Jauberteau, M.O. The Ins and Outs of Nanoparticle Technology in Neurodegenerative Diseases and Cancer. Curr. Drug Metab. 2015, 16, 609-632. [CrossRef] [PubMed]

115. Vardharajula, S.; Ali, S.Z.; Tiwari, P.M.; Eroğlu, E.; Vig, K.; Dennis, V.A.; Singh, S.R. Functionalized carbon nanotubes: Biomedical applications. Int. J. Nanomed. 2012, 7, 5361-5374.

116. Kafa, H.; Wang, J.T.W.; Rubio, N.; Venner, K.; Anderson, G.; Pach, E.; Ballesteros, B.; Preston, J.E.; Abbott, N.J.; Al-Jamal, K.T. The interaction of carbon nanotubes with an invitro blood-brain barrier model and mouse brain invivo. Biomaterials 2015, 53, 437-452. [CrossRef] [PubMed]

117. Erb-Zohar, K.; van Schanke, A.; Zimmermann, H.; Scheuenpflug, J.; Stobernack, H.-P.; Hulskotte, E.; Rübsamen-Schaeff, H.; Kropeit, D. Intravenous Hydroxypropyl $\beta$-Cyclodextrin Formulation of Letermovir: A Phase I, Randomized, Single-Ascending, and Multiple-Dose Trial. Clin. Transl. Sci. 2017, 10, 487-495. [CrossRef] [PubMed]

118. Arruda, D.C.; Hoffmann, C.; Charrueau, C.; Bigey, P.; Escriou, V. Innovative nonviral vectors for small-interferring RNA delivery and therapy. In Nanostructures for Novel Therapy: Synthesis, Characterization and Applications; Ficai, D., Mihai, A.G., Eds.; Elsevier: Amsterdam, The Netherlands, 2017; pp. 713-734.

119. Oku, N. Innovations in Liposomal DDS Technology and Its Application for the Treatment of Various Diseases. Biol. Pharm. Bull. Pharm. Bull. 2017, 40, 119-127. [CrossRef] [PubMed]

120. Kondiah, P.P.D.; Choonara, Y.E.; Kondiah, P.J.; Marimuthu, T.; Kumar, P.; du Toit, L.C.; Modi, G.; Pillay, V. Nanocomposites for therapeutic application in multiple sclerosis. In Applications of Nanocomposite Materials in Drug Delivery; Inamuddin, A.M., Asiri, A.M., Eds.; Woodhead: Sawston, UK, 2018; pp. 391-408.

121. Ramezani, M.; Khoshhamdam, M.; Dehshahri, A.; Malaekeh-Nikouei, B. The influence of size, lipid composition and bilayer fluidity of cationic liposomes on the transfection efficiency of nanolipoplexes. Colloids Surf. B Biointerfaces 2009, 72, 1-5. [CrossRef] [PubMed]

122. Gupta, Y.; Jain, A.; Jain, S.K. Transferrin-conjugated solid lipid nanoparticles for enhanced delivery of quinine dihydrochloride to the brain. J. Pharm. Pharmacol. 2007, 59, 935-940. [CrossRef] [PubMed] 
123. Riganti, C.; Muntoni, E.; Lanotte, M.; Peira, E.; Gallarate, M.; Chirio, D.; Corona, S.; Biasibetti, E.; Valazza, A.; Panciani, P.; et al. Positive-charged solid lipid nanoparticles as paclitaxel drug delivery system in glioblastoma treatment. Eur. J. Pharm. Biopharm. 2014, 88, 746-758.

124. Bahari, L.A.S.; Hamishehkar, H. The impact of variables on particle size of solid lipid nanoparticles and nanostructured lipid carriers: A comparative literature review. Adv. Pharm. Bull. 2016, 6, 143-151. [CrossRef] [PubMed]

125. Choi, K.O.; Choe, J.; Suh, S.; Ko, S. Positively charged nanostructured lipid carriers and their effect on the dissolution of poorly soluble drugs. Molecules 2016, 21, 672. [CrossRef] [PubMed]

126. Goh, W.J.; Zou, S.; Ong, W.Y.; Torta, F.; Alexandra, A.F.; Schiffelers, R.M.; Storm, G.; Wang, J.W.; Czarny, B.; Pastorin, G. Bioinspired Cell-Derived Nanovesicles versus Exosomes as Drug Delivery Systems: A Cost-Effective Alternative. Sci. Rep. 2017, 7, 14322. [CrossRef] [PubMed]

127. Tagalakis, A.D.; Meng, J.; McCarthy, D.; Syed, F.; Aldossary, A.M.; Maeshima, R.; Moghimi, S.M.; Yu-Wai-Man, C.; Hart, S.L.; Wu, L.-P. Peptide and nucleic acid-directed self-assembly of cationic nanovehicles through giant unilamellar vesicle modification: Targetable nanocomplexes for in vivo nucleic acid delivery. Acta Biomater. 2017, 51, 351-362. [CrossRef] [PubMed]

128. Von Storp, B.; Engel, A.; Boeker, A.; Ploeger, M.; Langer, K. Albumin nanoparticles with predictable size by desolvation procedure. J. Microencapsul. 2012, 29, 138-146. [CrossRef] [PubMed]

129. Lin, T.; Zhao, P.; Jiang, Y.; Tang, Y.; Jin, H.; Pan, Z.; He, H.; Yang, V.C.; Huang, Y. Blood-Brain-Barrier-Penetrating Albumin Nanoparticles for Biomimetic Drug Delivery via Albumin-Binding Protein Pathways for Antiglioma Therapy. ACS Nano 2016, 10, 9999-10012. [CrossRef] [PubMed]

130. Larsen, M.T.; Kuhlmann, M.; Hvam, M.L.; Howard, K.A. Albumin-based drug delivery: Harnessing nature to cure disease. Mol. Cell. Ther. 2016, 4, 3. [CrossRef] [PubMed]

131. Beisel, C.L.; Smolke, C.D. Design Principles for Riboswitch Function. PLoS Comput. Biol. 2009, 5, e1000363. [CrossRef] [PubMed]

132. Kim, J.Y.; Choi, W.I.; Kim, Y.H.; Tae, G. Brain-targeted delivery of protein using chitosan- and RVG peptide-conjugated, pluronic-based nano-carrier. Biomaterials 2013, 34, 1170-1178. [CrossRef] [PubMed]

133. Joshi, S.A.; Chavhan, S.S.; Sawant, K.K. Rivastigmine-loaded PLGA and PBCA nanoparticles: Preparation, optimization, characterization, in vitro and pharmacodynamic studies. Eur. J. Pharm. Biopharm. 2010, 76, 189-199. [CrossRef] [PubMed]

134. Li, J.; Sabliov, C. PLA/PLGA nanoparticles for delivery of drugs across the blood-brain barrier. Nanotechnol. Rev. 2013, 2, 241-257. [CrossRef]

135. Pillai, G.J.; Greeshma, M.M.; Menon, D. Impact of poly(lactic-co-glycolic acid) nanoparticle surface charge on protein, cellular and haematological interactions. Colloids Surf. B Biointerfaces 2015, 136, 1058-1066. [CrossRef] [PubMed]

136. Lim, J.; Kostiainen, M.; Maly, J.; Da Costa, V.C.P.; Annunziata, O.; Pavan, G.M.; Simanek, E.E. Synthesis of large dendrimers with the dimensions of small viruses. J. Am. Chem. Soc. 2013, 135, 4660-4663. [CrossRef] [PubMed]

137. Johnston, M.V.; Trent Magruder, J.; Grimm, J.C.; Lin, Y.-A.; Wilson, M.A.; Blue, M.E.; Sciortino, C.M.; Zhang, F.; Kannan, R.M.; Kannan, S.; et al. Generation-6 hydroxyl PAMAM dendrimers improve CNS penetration from intravenous administration in a large animal brain injury model. J. Control. Release 2017, 249, 173-182.

138. Li, Q.; Kartikowati, C.W.; Horie, S.; Ogi, T.; Iwaki, T.; Okuyama, K. Correlation between particle size/domain structure and magnetic properties of highly crystalline $\mathrm{Fe}_{3} \mathrm{O}_{4}$ nanoparticles. Sci. Rep. 2017, 7, 9894. [CrossRef] [PubMed]

139. Zhang, X.; Wu, D.; Shen, X.; Liu, P.; Yang, N.; Zhao, B.; Zhang, H.; Sun, Y.; Zhang, L.; Fan, F. Size-dependent in vivo toxicity of PEG-coated gold nanoparticles. Int. J. Nanomed. 2011, 6, 2071. [CrossRef] [PubMed]

140. Raval, J.P.; Joshi, P.; Chejara, D.R. Carbon nanotube for targeted drug delivery. In Applications of Nanocomposite Materials in Drug Delivery; Inamuddin, A.M., Asiri, A.M., Eds.; Woodhead: Sawston, UK, 2018; pp. 203-216.

141. Beutler, A.S. AAV Provides an Alternative for Gene Therapy of the Peripheral Sensory Nervous System. Mol. Ther. 2010, 18, 670-673. [CrossRef] [PubMed]

142. Fu, H.; McCarty, D.M. Crossing the blood-brain-barrier with viral vectors. Curr. Opin. Virol. 2016, $21,87-92$. [CrossRef] [PubMed] 
143. Bourdenx, M.; Dutheil, N.; Bezard, E.; Dehay, B. Systemic gene delivery to the central nervous system using Adeno-associated virus. Front. Mol. Neurosci. 2014, 7, 50. [CrossRef] [PubMed]

144. Foust, K.D.; Nurre, E.; Montgomery, C.L.; Hernandez, A.; Chan, C.M.; Kaspar, B.K. Intravascular AAV9 preferentially targets neonatal neurons and adult astrocytes. Nat. Biotechnol. 2009, 27, 59-65. [CrossRef] [PubMed]

145. Yang, B.; Li, S.; Wang, H.; Guo, Y.; Gessler, D.J.; Cao, C.; Su, Q.; Kramer, J.; Zhong, L.; Ahmed, S.S.; et al. Global CNS transduction of adult mice by intravenously delivered rAAVrh.8 and rAAVrh.10 and nonhuman primates by rAAVrh.10. Mol. Ther. 2014, 22, 1299-1309. [CrossRef] [PubMed]

146. Merkel, S.F.; Andrews, A.M.; Lutton, E.M.; Mu, D.; Hudry, E.; Hyman, B.T.; Maguire, C.A.; Ramirez, S.H. Trafficking of AAV vectors across a model of the blood-brain barrier: A comparative study of transcytosis and transduction using primary human brain endothelial cells. J. Neurochem. 2016, 140, 216-230. [CrossRef] [PubMed]

147. Passini, M.A.; Bu, J.; Richards, A.M.; Treleaven, C.M.; Sullivan, J.A.; O’Riordan, C.R.; Scaria, A.; Kells, A.P.; Samaranch, L.; San Sebastian, W.; et al. Translational Fidelity of Intrathecal Delivery of Self-Complementary AAV9-Survival Motor Neuron 1 for Spinal Muscular Atrophy. Hum. Gene Ther. 2014, 25, 619-630. [CrossRef] [PubMed]

148. Rashnonejad, A.; Chermahini, G.A.; Li, S.; Ozkinay, F.; Gao, G. Large-Scale Production of Adeno-Associated Viral Vector Serotype-9 Carrying the Human Survival Motor Neuron Gene. Mol. Biotechnol. 2016, 58, 30-36. [CrossRef] [PubMed]

149. Wirth, B.; Barkats, M.; Martinat, C.; Sendtner, M.; Gillingwater, T.H. Moving towards treatments for spinal muscular atrophy: Hopes and limits. Expert Opin. Emerg. Drugs 2015, 20, 353-356. [CrossRef] [PubMed]

150. Foust, K.D.; Wang, X.; McGovern, V.L.; Braun, L.; Bevan, A.K.; Haidet, A.M.; Le, T.T.; Morales, P.R.; Rich, M.M.; Burghes, A.H.M.; et al. Rescue of the spinal muscular atrophy phenotype in a mouse model by early postnatal delivery of SMN. Nat. Biotechnol. 2010, 28, 271-274. [CrossRef] [PubMed]

151. Fu, H.; Dirosario, J.; Killedar, S.; Zaraspe, K.; McCarty, D.M. Correction of neurological disease of mucopolysaccharidosis IIIB in adult mice by rAAV9 trans-blood-brain barrier gene delivery. Mol. Ther. 2011, 19, 1025-1033. [CrossRef] [PubMed]

152. McCarty, D.M.; DiRosario, J.; Gulaid, K.; Muenzer, J.; Fu, H. Mannitol-facilitated CNS entry of rAAV2 vector significantly delayed the neurological disease progression in MPS IIIB mice. Gene Ther. 2009, 16, 1340-1352. [CrossRef] [PubMed]

153. Zhang, H.; Yang, B.; Mu, X.; Ahmed, S.S.; Su, Q.; He, R.; Wang, H.; Mueller, C.; Sena-Esteves, M.; Brown, R.; et al. Several rAAV vectors efficiently cross the blood-brain barrier and transduce neurons and astrocytes in the neonatal mouse central nervous system. Mol. Ther. 2011, 19, 1440-1448. [CrossRef] [PubMed]

154. Louboutin, J.P.; Chekmasova, A.A.; Marusich, E.; Chowdhury, J.R.; Strayer, D.S. Efficient CNS gene delivery by intravenous injection. Nat. Methods 2010, 7, 905. [CrossRef] [PubMed]

155. Louboutin, J.P.; Marusich, E.; Fisher-Perkins, J.; Dufour, J.P.; Bunnell, B.A.; Strayer, D.S. Gene transfer to the rhesus monkey brain using SV40-derived vectors is durable and safe. Gene Ther. 2011, 18, 682-691. [CrossRef] [PubMed]

156. Hendricks, B.K.; Cohen-gadol, A.A.; Miller, J.C. Novel delivery methods bypassing the blood-brain and blood-tumor barriers. Neurosurg. Focus 2015, 38, 1-15. [CrossRef] [PubMed]

157. Shawkat, H.; Westwood, M.M.; Mortimer, A. Mannitol: A review of its clinical uses. Contin. Educ. Anaesth. Crit. Care Pain 2012, 12, 82-85. [CrossRef]

158. Thévenot, E.; Jordão, J.F.; O’Reilly, M.A.; Markham, K.; Weng, Y.-Q.; Foust, K.D.; Kaspar, B.K.; Hynynen, K.; Aubert, I. Targeted Delivery of Self-Complementary Adeno-Associated Virus Serotype 9 to the Brain, Using Magnetic Resonance Imaging-Guided Focused Ultrasound. Hum. Gene Ther. 2012, 23, 1144-1155. [CrossRef] [PubMed]

159. Weber-Adrian, D.; Thévenot, E.; O’Reilly, M.A.; Oakden, W.; Akens, M.K.; Ellens, N.; Markham-Coultes, K.; Burgess, A.; Finkelstein, J.; Yee, A.J.M.; et al. Gene delivery to the spinal cord using MRI-guided focused ultrasound. Gene Ther. 2015, 22, 568-577. [CrossRef] [PubMed]

160. Wang, S.; Olumolade, O.O.; Sun, T.; Samiotaki, G.; Konofagou, E.E. Noninvasive, neuron-specific gene therapy can be facilitated by focused ultrasound and recombinant adeno-associated virus. Gene Ther. 2015, 22, 104-110. [CrossRef] [PubMed] 
161. Friden, P.M.; Walus, L.R.; Musso, G.F.; Taylor, M.A.; Malfroy, B.; Starzyk, R.M. Anti-transferrin receptor antibody and antibody-drug conjugates cross the blood-brain barrier. Proc. Natl. Acad. Sci. USA 1991, 88, 4771-4775. [CrossRef] [PubMed]

162. Yu, Y.J.; Zhang, Y.; Kenrick, M.; Hoyte, K.; Luk, W.; Lu, Y.; Atwal, J.; Elliott, J.M.; Prabhu, S.; Watts, R.J.; et al. Boosting brain uptake of a therapeutic antibody by reducing its affinity for a transcytosis target. Sci. Transl. Med. 2011, 3, 84ra44. [CrossRef] [PubMed]

163. Lichota, J.; Skjørringe, T.; Thomsen, L.B.; Moos, T. Macromolecular drug transport into the brain using targeted therapy. J. Neurochem. 2010, 113, 1-13. [CrossRef] [PubMed]

164. Schwarze, S.R.; Ho, A.; Vocero-Akbani, A.; Dowdy, S.F. In vivo protein transduction: Delivery of a biologically active protein into the mouse. Science 1999, 285, 1569-1572. [CrossRef] [PubMed]

165. Ni, D.; Zhang, J.; Bu, W.; Xing, H.; Han, F.; Xiao, Q.; Yao, Z.; Chen, F.; He, Q.; Liu, J.; et al. Dual-targeting upconversion nanoprobes across the blood-brain barrier for magnetic resonance/fluorescence imaging of intracranial glioblastoma. ACS Nano 2014, 8, 1231-1242. [CrossRef] [PubMed]

166. Pardridge, W.M. Receptor-mediated peptide transport through the blood-brain barrier. Endocr. Rev. 1986, 7, 314-330. [CrossRef] [PubMed]

167. Wagner, S.; Kufleitner, J.; Zensi, A.; Dadparvar, M.; Wien, S.; Bungert, J.; Vogel, T.; Worek, F.; Kreuter, J.; von Briesen, H. Nanoparticulate transport of oximes over an in vitro blood-brain barrier model. PLoS ONE 2010, 5, e14213. [CrossRef] [PubMed]

168. Mishra, V.; Mahor, S.; Rawat, A.; Gupta, P.N.; Dubey, P.; Khatri, K.; Vyas, S.P. Targeted brain delivery of AZT via transferrin anchored pegylated albumin nanoparticles. J. Drug Target. 2006, 14, 45-53. [CrossRef] [PubMed]

169. Kumar, P.; Wu, H.; McBride, J.L.; Jung, K.E.; Hee Kim, M.; Davidson, B.L.; Kyung Lee, S.; Shankar, P.; Manjunath, N. Transvascular delivery of small interfering RNA to the central nervous system. Nature 2007, 448, 39-43. [CrossRef] [PubMed]

170. Oller-Salvia, B.; Sánchez-Navarro, M.; Giralt, E.; Teixidó, M. Blood-brain barrier shuttle peptides: An emerging paradigm for brain delivery. Chem. Soc. Rev. 2016, 45, 4690-4707. [CrossRef] [PubMed]

171. Chung, N.S.; Wasan, K.M. Potential role of the low-density lipoprotein receptor family as mediators of cellular drug uptake. Adv. Drug Deliv. Rev. 2004, 56, 1315-1334. [CrossRef] [PubMed]

172. Mutoh, M.; Komiya, M.; Teraoka, N.; Ueno, T.; Takahashi, M.; Kitahashi, T.; Sugimura, T.; Wakabayashi, K. Overexpression of low-density lipoprotein receptor and lipid accumulation in intestinal polyps in Min mice. Int. J. Cancer 2009, 125, 2505-2510. [CrossRef] [PubMed]

173. Spencer, B.J.; Verma, I.M. Targeted delivery of proteins across the blood-brain barrier. Proc. Natl. Acad. Sci. USA 2007, 104, 7594-7599. [CrossRef] [PubMed]

174. Wang, D.; El-Amouri, S.S.; Dai, M.; Kuan, C.-Y.; Hui, D.Y.; Brady, R.O.; Pan, D. Engineering a lysosomal enzyme with a derivative of receptor-binding domain of apoE enables delivery across the blood-brain barrier. Proc. Natl. Acad. Sci. USA 2013, 110, 2999-3004. [CrossRef] [PubMed]

175. Demeule, M.; Regina, A.; Che, C.; Poirier, J.; Nguyen, T.; Gabathuler, R.; Castaigne, J.-P.; Beliveau, R. Identification and Design of Peptides as a New Drug Delivery System for the Brain. J. Pharmacol. Exp. Ther. 2007, 324, 1064-1072. [CrossRef] [PubMed]

176. Bockenhoff, A.; Cramer, S.; Wolte, P.; Knieling, S.; Wohlenberg, C.; Gieselmann, V.; Galla, H.-J.; Matzner, U. Comparison of Five Peptide Vectors for Improved Brain Delivery of the Lysosomal Enzyme Arylsulfatase A. J. Neurosci. 2014, 34, 3122-3129. [CrossRef] [PubMed]

177. Rip, J.; Chen, L.; Hartman, R.; Van Den Heuvel, A.; Reijerkerk, A.; Van Kregten, J.; Van Der Boom, B.; Appeldoorn, C.; De Boer, M.; Maussang, D.; et al. Glutathione PEGylated liposomes: Pharmacokinetics and delivery of cargo across the blood-brain barrier in rats. J. Drug Target. 2014, 22, 460-467. [CrossRef] [PubMed]

178. Bachhawat, A.K.; Thakur, A.; Kaur, J.; Zulkifli, M. Glutathione transporters. Biochim. Biophys. Acta Gen. Subj. 2013, 1830, 3154-3164. [CrossRef] [PubMed]

179. Lee, J.H.; Engler, J.A.; Collawn, J.F.; Moore, B.A. Receptor mediated uptake of peptides that bind the human transferrin receptor. Eur. J. Biochem. 2001, 268, 2004-2012. [CrossRef] [PubMed]

180. Prades, R.; Guerrero, S.; Araya, E.; Molina, C.; Salas, E.; Zurita, E.; Selva, J.; Egea, G.; López-Iglesias, C.; Teixidó, M.; et al. Delivery of gold nanoparticles to the brain by conjugation with a peptide that recognizes the transferrin receptor. Biomaterials 2012, 33, 7194-7205. [CrossRef] [PubMed] 
181. Zhang, X.; He, T.; Chai, Z.; Samulski, R.J.; Li, C. Blood-brain barrier shuttle peptides enhance AAV transduction in the brain after systemic administration. Biomaterials 2018, 176, 71-83. [CrossRef] [PubMed]

182. Zhang, B.; Sun, X.; Mei, H.; Wang, Y.; Liao, Z.; Chen, J.; Zhang, Q.; Hu, Y.; Pang, Z.; Jiang, X. LDLR-mediated peptide-22-conjugated nanoparticles for dual-targeting therapy of brain glioma. Biomaterials 2013, 34, 9171-9182. [CrossRef] [PubMed]

183. Teixidó, M.; Zurita, E.; Malakoutikhah, M.; Tarragó, T.; Giralt, E. Diketopiperazines as a tool for the study of transport across the Blood-Brain Barrier (BBB) and their potential use as BBB-shuttles. J. Am. Chem. Soc. 2007, 129, 11802-11813. [CrossRef] [PubMed]

184. Malakoutikhah, M.; Pradesh, R.; Teixidó, M.; Giralt, E. N-Methyl Phenylalanine-Rich peptides as highly versatile blood-brain barrier shuttles. J. Med. Chem. 2010, 53, 2354-2363. [CrossRef] [PubMed]

185. Malakoutikhah, M.; Teixidó, M.; Giralt, E. Toward an optimal blood-brain barrier shuttle by synthesis and evaluation of peptide libraries. J. Med. Chem. 2008, 51, 4881-4889. [CrossRef] [PubMed]

186. Arranz-Gibert, P.; Guixer, B.; Malakoutikhah, M.; Muttenthaler, M.; Guzmán, F.; Teixidó, M.; Giralt, E. Lipid Bilayer Crossing-The Gate of Symmetry. Water-Soluble Phenylproline-Based Blood-Brain Barrier Shuttles. J. Am. Chem. Soc. 2015, 137, 7357-7364. [CrossRef] [PubMed]

187. Couture, O.; Foley, J.; Kassell, N.; Larrat, B.; Aubry, J.-F. Review of ultrasound mediated drug delivery for cancer treatment: Updates from pre-clinical studies. Transl. Cancer Res. 2014, 3, 494-511.

188. Snipstad, S.; Sulheim, E.; de Lange Davies, C.; Moonen, C.; Storm, G.; Kiessling, F.; Schmid, R.; Lammers, T. Sonopermeation to improve drug delivery to tumors: From fundamental understanding to clinical translation. Expert Opin. Drug Deliv. 2018, 15, 1249-1261. [CrossRef] [PubMed]

189. Theek, B.; Baues, M.; Ojha, T.; Möckel, D.; Veettil, S.K.; Steitz, J.; Van Bloois, L.; Storm, G.; Kiessling, F.; Lammers, T. Sonoporation enhances liposome accumulation and penetration in tumors with low EPR. J. Control. Release 2016, 231, 77-85. [CrossRef] [PubMed]

190. Burke, C.W.; Hsiang, Y.H.J.; Alexander IV, E.; Kilbanov, A.L.; Price, R.J. Covalently linking poly(lactic-co-glycolic acid) nanoparticles to microbubbles before intravenous injection improves their ultrasound-targeted delivery to skeletal muscle. Small 2011, 7, 1227-1235. [CrossRef] [PubMed]

191. De Temmerman, M.L.; Dewitte, H.; Vandenbroucke, R.E.; Lucas, B.; Libert, C.; Demeester, J.; De Smedt, S.C.; Lentacker, I.; Rejman, J. MRNA-Lipoplex loaded microbubble contrast agents for ultrasound-assisted transfection of dendritic cells. Biomaterials 2011, 32, 9128-9135. [CrossRef] [PubMed]

192. Burgess, A.; Ayala-Grosso, C.A.; Ganguly, M.; Jordão, J.F.; Aubert, I.; Hynynen, K. Targeted delivery of neural stem cells to the brain using MRI-guided focused ultrasound to disrupt the blood-brain barrier. PLoS ONE 2011, 6, e27877. [CrossRef] [PubMed]

193. Huang, Q.; Deng, J.; Xie, Z.; Wang, F.; Chen, S.; Lei, B.; Liao, P.; Huang, N.; Wang, Z.; Wang, Z.; et al. Effective Gene Transfer into Central Nervous System Following Ultrasound-Microbubbles-Induced Opening of the Blood-Brain Barrier. Ultrasound Med. Biol. 2012, 38, 1234-1243. [CrossRef] [PubMed]

194. Chertok, B.; Langer, R. Circulating magnetic microbubbles for localized real-time control of drug delivery by ultrasonography-guided magnetic targeting and ultrasound. Theranostics 2018, 8, 341-357. [CrossRef] [PubMed]

195. Song, C.W. Effect of local hyperthermia on blood flow and microenvironment: A review. Cancer Res. 1984, 44, 4721s-4730s. [PubMed]

196. Kong, G.; Anyarambhatla, G.; Petros, W.P.; Braun, R.D.; Colvin, O.M.; Needham, D.; Dewhirst, M.W. Efficacy of liposomes and hyperthermia in a human tumor xenograft model: Importance of triggered drug release. Cancer Res. 2000, 60, 6950-6957. [PubMed]

197. Yudina, A.; Moonen, C. Ultrasound-induced cell permeabilisation and hyperthermia: Strategies for local delivery of compounds with intracellular mode of action. Int. J. Hyperth. 2012, 28, 311-319. [CrossRef] [PubMed]

198. Husseini, G.A.; Pitt, W.G.; Martins, A.M. Ultrasonically triggered drug delivery: Breaking the barrier. Colloids Surf. B Biointerfaces 2014, 123, 364-386. [CrossRef] [PubMed]

199. Grüll, H.; Langereis, S. Hyperthermia-triggered drug delivery from temperature-sensitive liposomes using MRI-guided high intensity focused ultrasound. J. Control. Release 2012, 161, 317-327. [CrossRef] [PubMed]

200. Kong, G.; Dewhirst, M.W. Hyperthermia and liposomes. Int. J. Hyperth. 1999, 15, 345-370.

201. Jain, A.; Tiwari, A.; Verma, A.; Jain, S.K. Ultrasound-based triggered drug delivery to tumors. Drug Deliv. Transl. Res. 2018, 8, 150-164. [CrossRef] [PubMed] 
202. Yudina, A.; Lepetit-Coiffé, M.; Moonen, C.T.W. Evaluation of the temporal window for drug delivery following ultrasound-mediated membrane permeability enhancement. Mol. Imaging Biol. 2011, 13, 239-249. [CrossRef] [PubMed]

203. Kovacs, Z.I.; Kim, S.; Jikaria, N.; Qureshi, F.; Milo, B.; Lewis, B.K.; Bresler, M.; Burks, S.R.; Frank, J.A. Disrupting the blood-brain barrier by focused ultrasound induces sterile inflammation. Proc. Natl. Acad. Sci. USA 2017, 114, E75-E84. [CrossRef] [PubMed]

204. Silburt, J.; Lipsman, N.; Aubert, I. Disrupting the blood-brain barrier with focused ultrasound: Perspectives on inflammation and regeneration. Proc. Natl. Acad. Sci. USA 2017, 114, E6735-E6736. [CrossRef] [PubMed]

205. McDannold, N.; Vykhodtseva, N.; Raymond, S.; Jolesz, F.A.; Hynynen, K. MRI-guided targeted blood-brain barrier disruption with focused ultrasound: Histological findings in rabbits. Ultrasound Med. Biol. 2005, 31, 1527-1537. [CrossRef] [PubMed]

206. Lochhead, J.J.; Thorne, R.G. Intranasal delivery of biologics to the central nervous system. Adv. Drug Deliv. Rev. 2012, 64, 614-628. [CrossRef] [PubMed]

207. Erdő, F.; Bors, L.A.; Farkas, D.; Bajza, Á.; Gizurarson, S. Evaluation of intranasal delivery route of drug administration for brain targeting. Brain Res. Bull. 2018, 143, 155-170. [CrossRef] [PubMed]

208. Bynoe, M.S.; Viret, C.; Yan, A.; Kim, D.G. Adenosine receptor signaling: A key to opening the blood-brain door. Fluids Barriers CNS 2015, 12, 20. [CrossRef] [PubMed]

209. Mills, J.H.; Alabanza, L.M.; Mahamed, D.A.; Bynoe, M.S. Extracellular adenosine signaling induces CX3CL1 expression in the brain to promote experimental autoimmune encephalomyelitis. J. Neuroinflamm. 2012, 9, 193. [CrossRef] [PubMed]

210. Bors, L.A.; Bajza, Á.; Kocsis, D.; Erdő, F. Caffeine: Traditional and new therapeutic indications and use as a dermatological model drug-A review. Orvosi Hetil. 2018, 159, 384-390. [CrossRef] [PubMed]

211. Vazana, U.; Veksler, R.; Pell, G.S.; Prager, O.; Fassler, M.; Chassidim, Y.; Roth, Y.; Shahar, H.; Zangen, A.; Raccah, R.; et al. Glutamate-Mediated Blood-Brain Barrier Opening: Implications for Neuroprotection and Drug Delivery. J. Neurosci. 2016, 36, 7727-7739. [CrossRef] [PubMed]

212. Zybina, A.; Anshakova, A.; Malinovskaya, J.; Melnikov, P.; Baklaushev, V.; Chekhonin, V.; Maksimenko, O.; Titov, S.; Balabanyan, V.; Kreuter, J.; et al. Nanoparticle-based delivery of carbamazepine: A promising approach for the treatment of refractory epilepsy. Int. J. Pharm. 2018, 547, 10-23. [CrossRef] [PubMed]

213. Klukovits, A.; Krajcsi, P. Mechanisms and therapeutic potential of inhibiting drug efflux transporters. Expert Opin. Drug Metab. Toxicol. 2015, 11, 907-920. [CrossRef] [PubMed]

214. Choo, E.F.; Leake, B.; Wandel, C.; Imamura, H.; Wood, A.J.J.; Wilkinson, G.R.; Kim, R.B. Pharmacological inhibition of P-glycoprotein transport enhances the distribution of HIV-1 protease inhibitors into brain and testes. Drug Metab. Dispos. 2000, 28, 655-660. [PubMed]

215. Kemper, E.M.; Van Zandbergen, A.E.; Cleypool, C.; Mos, H.A.; Boogerd, W.; Beijnen, J.H.; Van Tellingen, O. Increased penetration of paclitaxel into the brain by inhibition of P-glycoprotein. Clin. Cancer Res. 2003, 9 , 2849-2855. [PubMed]

216. Dagenais, C.; Graff, C.L.; Pollack, G.M. Variable modulation of opioid brain uptake by P-glycoprotein in mice. Biochem. Pharmacol. 2004, 67, 269-276. [CrossRef] [PubMed]

217. Calatozzolo, C.; Gelati, M.; Ciusani, E.; Sciacca, F.L.; Pollo, B.; Cajola, L.; Marras, C.; Silvani, A.; Vitellaro-Zuccarello, L.; Croci, D.; et al. Expression of drug resistance proteins Pgp, MRP1, MRP3, MRP5 AND GST- $\pi$ in human glioma. J. Neurooncol. 2005, 74, 113-121. [CrossRef] [PubMed]

218. Dauchy, S.; Dutheil, F.; Weaver, R.J.; Chassoux, F.; Daumas-Duport, C.; Couraud, P.O.; Scherrmann, J.M.; De Waziers, I.; Declèves, $\mathrm{X}$. ABC transporters, cytochromes P450 and their main transcription factors: Expression at the human blood-brain barrier. J. Neurochem. 2008, 107, 1518-1528. [CrossRef] [PubMed]

219. Polli, J.W.; Olson, K.L.; Chism, J.P.; John-Williams, L.S.; Yeager, R.L.; Woodard, S.M.; Otto, V.; Castellino, S.; Demby, V.E. An unexpected synergist role of P-glycoprotein and breast cancer resistance protein on the central nervous system penetration of the tyrosine kinase inhibitor lapatinib ( $N-\{3-C h l o r o-4-[(3-$ fluorobenzyl)oxy]phenyl\}-6-[5-(\{[2-(methylsulfonyl)ethyl]amino\}methyl)-2-furyl]-4-quinazolinamine; GW572016). Drug Metab. Dispos. 2009, 37, 439-442. [PubMed]

220. Zamek-Gliszczynski, M.J.; Kalvass, J.C.; Pollack, G.M.; Brouwer, K.L.R. Relationship between drug/metabolite exposure and impairment of excretory transport function. Drug Metab. Dispos. 2009, 37, 386-390. [CrossRef] [PubMed] 
221. Lu, C.T.; Zhao, Y.Z.; Wong, H.L.; Cai, J.; Peng, L.; Tian, X.Q. Current approaches to enhance CNS delivery of drugs across the brain barriers. Int. J. Nanomed. 2014, 9, 2241-2257. [CrossRef] [PubMed]

222. Westphal, M.; Hilt, D.C.; Bortey, E.; Delavault, P.; Olivares, R.; Warnke, P.C.; Whittle, I.R.; Jääskeläinen, J.; Ram, Z. A phase 3 trial of local chemotherapy with biodegradable carmustine (BCNU) wafers (Gliadel wafers) in patients with primary malignant glioma. Neuro. Oncol. 2003, 5, 79-88. [CrossRef] [PubMed]

223. Vukelja, S.; Anthony, S.; Arseneau, J.; Berman, B.; Cunningham, C.; Nemunaitis, J.; Samlowski, W.; Fowers, K. Phase 1 study of escalating-dose OncoGel (ReGel/paclitaxel) depot injection, a controlled-release formulation of paclitaxel, for local management of superficial solid tumor lesions. Anticancer Drugs. 2007, 18, 283-289. [CrossRef] [PubMed]

224. Sheleg, S.V.; Korotkevich, E.A.; Zhavrid, E.A.; Muravskaya, G.V.; Smeyanovich, A.F.; Shanko, Y.G.; Yurkshtovich, T.L.; Bychkovsky, P.B.; Belyaev, S.A. Local chemotherapy with cisplatin-depot for glioblastoma multiforme. J. Neurooncol. 2002, 60, 53-59. [CrossRef] [PubMed]

225. DiMeco, F.; Li, K.W.; Tyler, B.M.; Wolf, A.S.; Brem, H.; Olivi, A. Local delivery of mitoxantrone for the treatment of malignant brain tumors in rats. J. Neurosurg. 2002, 97, 1173-1178. [CrossRef] [PubMed]

226. Aschauer, D.F.; Kreuz, S.; Rumpel, S. Analysis of Transduction Efficiency, Tropism and Axonal Transport of AAV Serotypes 1, 2, 5, 6, 8 and 9 in the Mouse Brain. PLoS ONE 2013, 8, e76310. [CrossRef] [PubMed]

227. Xue, Y.Q.; Ma, B.F.; Zhao, L.R.; Tatom, J.B.; Li, B.; Jiang, L.X.; Klein, R.L.; Duan, W.M. AAV9-mediated erythropoietin gene delivery into the brain protects nigral dopaminergic neurons in a rat model of Parkinson's disease. Gene Ther. 2010, 17, 83-94. [CrossRef] [PubMed]

228. Green, F.; Samaranch, L.; Zhang, H.S.; Manning-Bog, A.; Meyer, K.; Forsayeth, J.; Bankiewicz, K.S. Axonal transport of AAV9 in nonhuman primate brain. Gene Ther. 2016, 23, 520-526. [CrossRef] [PubMed]

229. Swain, G.P.; Prociuk, M.; Bagel, J.H.; O’Donnell, P.; Berger, K.; Drobatz, K.; Gurda, B.L.; Haskins, M.E.; Sands, M.S.; Vite, C.H. Adeno-associated virus serotypes 9 and rh10 mediate strong neuronal transduction of the dog brain. Gene Ther. 2014, 21, 28-36. [CrossRef] [PubMed]

230. Davidson, B.; Stein, C.; Heth, J.; Martins, I.; Kotin, R.; Derksen, T.; Zabner, J.; Ghodsi, A.; Chiorini, J. Recombinant adeno-associated virus type 2, 4, and 5 vectors: Transduction of variant cell types and regions in the mammalian central nervous system. Proc. Natl. Acad. Sci. USA 2000, 97, 3428-3432. [CrossRef] [PubMed]

231. Lin, J.; Zhou, H.; Zhang, N.; Yin, B.; Sheng, H.S. Effects of the implantation of Ommaya reservoir in children with tuberculous meningitis hydrocephalus: A preliminary study. Childs Nerv. Syst. 2012, 28, 1003-1008. [CrossRef] [PubMed]

232. Szvalb, A.D.; Raad, I.I.; Weinberg, J.S.; Suki, D.; Mayer, R.; Viola, G.M. Ommaya reservoir-related infections: Clinical manifestations and treatment outcomes. J. Infect. 2014, 68, 216-224. [CrossRef] [PubMed]

233. Raffa, R.B.; Pergolizzi, J.V. Intracerebroventricular opioids for intractable pain. Br. J. Clin. Pharmacol. 2012, 74, 34-41. [CrossRef] [PubMed]

234. Ballantyne, J.C.; Carwood, C.; Gupta, A.; Bennett, M.I.; Simpson, K.H.; Dhandapani, K.; Lynch, L.; Baranidharan, G. Comparative efficacy of epidural, subarachnoid, and intracerebroventricular opioids in patients with pain due to cancer. Cochrane Database Syst. Rev. 2005, CD005178. [CrossRef]

235. Ruggiero, A.; Conter, V.; Milani, M.; Biagi, E.; Lazzareschi, I.; Sparano, P.; Riccardi, R. Intrathecal chemotherapy with antineoplastic agents in children. Paediatr. Drugs 2001, 3, 237-246. [CrossRef] [PubMed]

236. Scheld, W.M. Drug delivery to the central nervous system: General principles and relevance to therapy for infections of the central nervous system. Rev. Infect. Dis. 1989, 11, S1669-S1690. [CrossRef] [PubMed]

237. Sladek, J.; Gash, D. Nerve-cell grafting in Parkinson's disease. J. Neurosurg. 1988, 68, 337-351. [CrossRef] [PubMed]

238. Leigh, K.; Elisevich, K.; Rogers, K.A. Vascularization and microvascular permeability in solid versus cell-suspension embryonic neural grafts. J. Neurosurg. 1994, 81, 272-283. [CrossRef] [PubMed]

(C) 2019 by the authors. Licensee MDPI, Basel, Switzerland. This article is an open access article distributed under the terms and conditions of the Creative Commons Attribution (CC BY) license (http:/ / creativecommons.org/licenses/by/4.0/). 